\title{
Permian endemic bivalves of the "Irati anoxic event", Paraná Basin, Brazil: Taphonomical, paleogeographical and evolutionary implications
}

\author{
Suzana Aparecida Matos ${ }^{\text {a,* }}$, Lucas Verissimo Warren ${ }^{\text {b }}$, Filipe Giovanini Varejão ${ }^{\text {b }}$, \\ Mario Luis Assine ${ }^{\mathrm{b}}$, Marcello Guimarães Simões ${ }^{\mathrm{c}}$ \\ a Instituto de Geociências, Programa de Pós-graduação em Geoquímica e Geotectônica, Universidade de São Paulo, Rua do Lago 562, São Paulo, SP. 05508-080, Brazil \\ b Instituto de Geociências e Ciências Exatas, Departamento de Geologia Aplicada, Universidade Estadual Paulista, Avenida 24-A, Bela Vista, 178, Rio Claro, SP 13506-900, Brazil \\ c Instituto de Biociências, Departamento de Zoologia, Universidade Estadual Paulista, Distrito de Rubião Junior s/n, 510, Botucatu, SP 18.618-970, Brazil
}

\section{A R T I C L E I N F O}

\section{Article history:}

Received 5 January 2016

Received in revised form 20 December 2016

Accepted 29 December 2016

Available online 30 December 2016

\section{Keywords:}

Anoxic crisis

Black shales

Endemic bivalves

Allochthonous shells

Permian

Southern Gondwana

\begin{abstract}
A B S T R A C T
Anoxic to dysoxic conditions must have existed in the Paraná Basin during the deposition of the Permian oil-bearing shales of the Irati Formation, reflecting the marine isolation of the basin from the Panthalassic Ocean. In this environment, benthic invertebrates are extremely rare, in contrast to the overlying Serra Alta and Teresina formations, which were deposited in dysoxic/oxic waters, respectively. Hence, the abundant shallow-burrowing, endemic bivalves recorded in the shales of the basal portion of the Irati Formation are one of the most distinctive features of this stratigraphic interval. Their preservation in offshore deposits is, however, a product of storm flows in shallow waters that swept the shells to distal settings. Subsequently, these were sorted by long-lasting shelf currents that produced dense $\left(2-5\right.$ shells $\left./ 20 \mathrm{~cm}^{2}\right)$ pavements in which shells in a hydrodynamically stable posture (convex-up) predominate, forming thin, complex shell concentrations despite their simple internal stratigraphy. The new data presented here have important paleoecologic, paleogeographic and evolutionary implications and indicate that (a) during the deposition of the oil-rich shales of the Irati Formation, numerous benthic bivalves thrived in the contemporary shallow-water bottoms of the Paraná Basin; (b) the mono- to paucispecific nature of the studied shell-rich pavements is, in part, due to hydrologic shell transport; and (c) restricted connections to open ocean waters (Panthalassa) existed during Irati times. Therefore, the origin of the endemic Passa Dois molluscan fauna occurred somewhere between the interval represented by the underlying Palermo Formation and the basal portion of the Irati Formation. Finally, these endemic bivalves appeared at least $\sim 10$ million years earlier than previously thought.
\end{abstract}

(C) 2016 Elsevier B.V. All rights reserved.

\section{Introduction}

During the Permian (Cisuralian-early Guadalupian), the eastern intraplate basins of southern Gondwana (sensu Limarino et al., 2014) were flooded by a huge epeiric sea. In some basins (e.g., the Paraná and Chaco-Paraná basins), the development of this restricted interior sea was accompanied by the appearance of a diverse, endemic, bivalve-dominated assemblage known as the Passa Dois Group molluscan fauna (Mendes, 1952; Runnegar and Newell, 1971). This fauna is known worldwide for its diversity, abundance, high degree of endemicity and complex evolutionary history (Simões et al., 1998; Wesselingh, 2007). In fact, it is considered to be the oldest molluscan-bearing, long-lived, restricted sea fauna (Wesselingh, 2007) and was mainly dominated by the Edmondioidea (Pachydomidae) and Crassatelloidea

\footnotetext{
* Corresponding author.

E-mail addresses: sumatos.s@gmail.com (S.A. Matos), warren@rc.unesp.br (L.V. Warren), filipe.varejao@hotmail.com (F.G. Varejão), assine@rc.unesp.br (M.L. Assine), profmgsimoes@gmail.com (M.G. Simões).
}

(Astartidae) (Runnegar and Newell, 1971; Simões et al., 1998). Members of this fauna were also recorded in coeval successions of the Huab (Namibia) (Holzfoerster, 2000, 2002; Stollhofen et al., 2000; Wanke, 2000; David et al., 2011) and Karoo (South Africa) basins (Cooper and Kensley, 1984; David, 2014). However, the best records in terms of abundance and preservation quality are found in the eastern border of the Paraná Basin, Brazil. During its 38 million years history (Artinskian-Changhsingian), this basin had limited or no connections with the Panthalassa Ocean and was subjected to important climatic oscillations (Hachiro et al., 1993). These effects produced third-order cycles of sea level fluctuations (Holz et al., 2010a) that periodically caused variations in salinity (hypersaline, brackish, and freshwater) and oxygen (anoxic to oxic bottoms) (Schneider et al., 1974; Zalán et al., 1991; Milani et al., 1994; Rohn, 1994; Simões et al., 1998; Wesselingh, 2007; Holz et al., 2010a; Bondioli et al., 2015; Warren et al., 2015).

The Passa Dois Group succession begins with the extensive deposition of the shales of the Irati Formation and coeval units in the Huab and Karoo basins. These shales record widespread dysoxic to anoxic 
conditions (Araújo, 2001; Araújo et al., 2001; Milani et al., 2007; Holz et al., 2010a), and are succeeded by a brief transgressive cycle (Serra Alta Formation). Deposition of this last unit is followed by a large-scale regressive phase (Teresina and Corumbataí formations) that ended with the establishment of the transitional and continental deposits (fluvial, deltaic and eolian) of the Rio do Rasto Formation (Zalán et al., 1991; Sousa et al., 1991; Rohn, 1994; Simões et al., 1998, 2015; Wesselingh, 2007; Warren et al., 2008, 2015; Holz et al., 2010a).

The best records of the Passa Dois molluscan fauna (Fig. 1) are found in the shallow-water deposits of the Teresina and Corumbataí formations and the basal portion of the overlying Rio do Rasto Formation (Mendes, 1952; Runnegar and Newell, 1971; Simões et al., 1998, 2015; David, 2014). Until now, only brief reports were known of the presence of bivalves in the oil-rich shales of the Irati Formation. Hence, the sudden appearance and environmental tolerance of this morphologically diverse bivalve fauna are outstanding issues in South American Gondwana geology (see Runnegar and Newell, 1971, p. 15). The bivalve genera of the Teresina, Corumbataí and Rio do Rasto (Serrinha Member) formations are commonly found in shallow-water deposits (Simões et al., 1996, 1998; Simões and Kowalewski, 1998) and it is reasonable to assume that their ancestors may also have flourished in a coastal or transitional settings (Runnegar and Newell, 1971, p. 15). These authors also suggested that the best places to search for the ancestors of the Passa Dois bivalves may be the marginalequivalent deposits of the Irati Formation where a shallow-water fauna might have thrived. They envisaged a paleogeographic scenario similar to that of the Cenozoic evolution of the Black and Caspian seas, in which anoxic waters are found in the deeper parts of the basin (below $100 \mathrm{~m}$ ). Hence, benthic organisms are restricted to the margins, and their distributions are sharply reflected in the lithofacies distribution (Runnegar and Newell, 1971). They also argued that "if the bivalve fauna of the Paraná Basin had a similar distribution at the time of deposition of the Irati Formation, most, if not all, of its record may have been lost through subsequent erosion of the basin margins" (Runnegar and Newell, 1971, p. 15; but see also Beurlen, 1954, 1957a for similar reasoning). Indeed, data from sedimentary facies distributions and isopach and basement structural maps of the Paraná Basin suggest that the Permian units extended further eastwards (towards offshore) and constituted the basement of the Pelotas and Santos basins generated during the Gondwana rifting phase (Holz et al., 2010b, and references therein). In other words, part of the geological record of the late Paleozoic Gondwana succession of the Paraná Basin was indeed lost. Viewed from this perspective, solving the enigmatic absence of benthic invertebrates during Irati times seems difficult because of a major preservational megabias (i.e., the lack of records of contemporary shallow-water sedimentary facies).

In this work, we approached the above issues from a new perspective. On the basis of a few hidden reports and unpublished data, we focused our efforts in searching for bivalve fossils on the distal anoxic deposits of the Irati Formation, where the presence of benthic

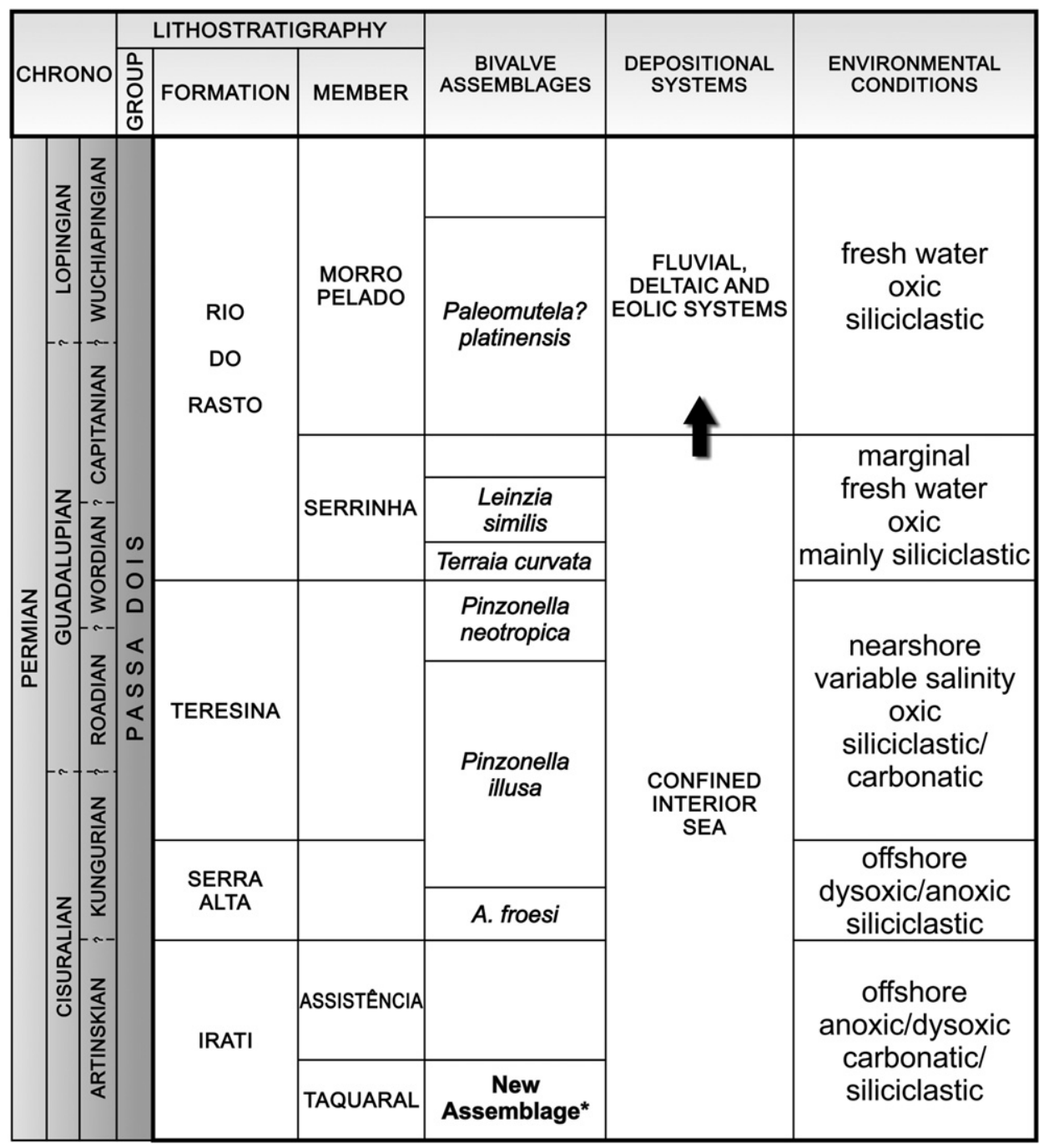

Fig. 1. Stratigraphic distribution of the Permian bivalve assemblages, Passa Dois Group, Paraná Basin, Brazil. Note $\left({ }^{*}\right)$ the new assemblage at the basal portion of the succession. Modified from Rohn (1994, 2007). 
invertebrates is unexpected. In fact, a critical review of the available sedimentologic and taphonomic information about the Irati Formation indicates that some levels within the shales may correspond to distal deposits generated by episodic events (Lavina et al., 1991; Soares, 2003; Matos et al., 2013). Such events could entrain sediment and mollusks from contemporary shallow water bottoms, which were transported to offshore settings by high-energy flows (see Brett et al., 2012a, 2012b for similar Devonian and Fürsich et al., 2016, for Jurassic examples). In this context, we document for the first time the presence of an abundant molluscan fauna that thrived nearshore during the Irati dysoxic-anoxic event. These data are noteworthy and diametrically opposite to the general belief that benthic invertebrates were almost absent in the Paraná Basin during the deposition of the Irati Formation. Our results are significant for several reasons, since they (a) fill a critical gap in the evolutionary model of the Passa Dois Group molluscan fauna, as proposed by Runnegar and Newell (1971) and refined by Simões et al. (1998), and (b) allow us to explore the possible taphonomic pathways responsible for the preservation of shallow-water mollusks in contemporary offshore facies.

\section{Background}

\subsection{The long search for the missing bivalves}

As noted above, the Permian Passa Dois Group encompasses the distal (anoxic to dysoxic) deposits of the Irati and Serra Alta formations, as well as the proximal (oxic) deposits of the Teresina, Corumbataí and Rio do Rasto formations (Fig. 1). Abundant and well-preserved silicified bivalves are recorded in the bioclastic sandstones (Simões and Kowalewski, 1998), centimeter-thick shell-beds or coquinas (Simões et al., 1996) and oolitic grainstones (Neves et al., 2010, 2011) of the Teresina and Corumbataí formations. Therefore, the majority of the paleontological studies focused on those shell-rich deposits. In contrast, the monotonous and fossil-poor shales and mudstones of the Irati and Serra Alta formations are frequently overlooked for benthic macrofossils (see Bondioli, 2014; Bondioli et al., 2015; Warren et al., 2015 for exceptions). Hence, an analytical bias exists in the paleontological investigations of the sedimentary succession of the Passa Dois Group, i.e., the distal deposits are less explored. Therefore, a consensual belief exists that the black pelitic facies of the basal portion of the Passa Dois Group are almost devoid of benthic invertebrates.

The above statement seems justifiable, given the widespread occurrence of organic-rich and unbioturbated shales in the Irati Formation. However, a detailed analysis of the sparse literature information revealed that the shales may yield benthic invertebrates. For example, in a brief talk given in 1956 during a scientific meeting of the Brazilian Academy of Sciences, the German paleontologist Karl Beurlen mentioned the first occurrence of tiny bivalves in the Irati Formation in the shales of a borehole log. Unfortunately, detailed information about this occurrence never appeared. The same author made a new report on the occurrence of bivalves in shales of the Irati Formation in 1957. The fossil (a single complete and poorly preserved left valve) was found $\sim 30 \mathrm{~m}$ above the basal portion of the Irati Formation (Beurlen, 1957b; Runnegar and Newell, 1971, p. 57). The rare specimen was assigned as a new species of Maackia (M. iratiensis), the dominant genus in the bivalve assemblages of the overlying Serra Alta Formation (Bondioli, 2014; Bondioli et al., 2015; Warren et al., 2015; Matos, 2016). Regrettably, repository information on the specimen (collection and reference number) is not available in Beurlen's brief note, and this fossil is probably lost.

New reports of the occurrence of bivalves in the Irati Formation only became available at the beginning of the new century. In 2002, the geologist Márcio Kazubek contacted the senior author of this contribution (MGS) to report the finding of small bivalves in shales of the Irati Formation (Taquaral Member) in southern Brazil. He called our attention to the fact that the fossils were amazingly abundant in some bedding planes (30,000-45,000/m², Kazubek and Simões, 2003b), which could be laterally tracked for tens of kilometers. Given the rarity of benthic invertebrates in the Irati Formation, this information was astonishing. Unfortunately, Kazubek could not study those fossils, but a small collection was donated to the scientific collection of the Department of Zoology, São Paulo State University, Botucatu campus (see Kazubek and Simões, 2002, 2003a, 2003b). Concomitantly, Rohn et al. (2003) and Lages (2004) also mentioned the occurrence of small bivalves in borehole samples from the base of the Irati Formation (i.e., the Taquaral Member) (Fig. 2). In all those cases, the bivalves were not identified, described or illustrated.

More recently, during a broad study of the basal portion of the Passa Dois Group (see Bondioli et al., 2015; Warren et al., 2015), we had an opportunity to study the Irati Formation at its type locality in southern Brazil. Following the information provided by Márcio Kazubek, we explored the basal deposits of the Irati Formation (Taquaral Member) in the vicinity of the homonymous city in the State of Paraná. Our results largely confirmed the observations of Kazubek and Simões (2003a, 2003b), i.e., bivalves can be amazingly abundant in some horizons of the basal portion of the Irati Formation. Therefore, we can now shed light on the dynamics of benthic ecosystems that existed during a critical interval of the Late Paleozoic history of the Paraná Basin-namely, the Irati anoxic event-as well as the taphonomic and sedimentologic processes responsible for the generation of the shell-rich concentrations in the offshore muds.

\subsection{The early Permian Irati anoxic event}

The Permian Irati Formation (Almeida and Barbosa, 1953) comprises the basal portion of the Passa Dois Group (Fig. 1) and was deposited following a large postglacial transgression that flooded the Paraná Basin during much of the early Permian (Zalán et al., 1991; Milani et al., 1994, 2007; Holz et al., 2010a; Limarino et al., 2014) (Fig. 3). During the deposition of the Irati Formation, the Paraná Basin was a huge $\left(>1.300,000 \mathrm{~km}^{2}\right)$, closed, inland, oxic to anoxic body of water (Araújo, 2001). The Irati Formation also records a unique moment in the intracratonic Paraná Basin when its connection with the Panthalassic Ocean was definitively closed (Milani et al., 2007). During the Lower to Middle Permian, the collision of the Patagonian terrane against southwestern Gondwana was responsible for the deformation of the Ventania Fold Belt (López Gamundi et al., 1995), which isolated the Paraná Basin from the Panthalassa (Milani et al., 2007). Due to the distance of the Gondwanides Orogen, the deposition of the Irati Formation occurred under relatively stable tectonic conditions, and the basin paleorelief was almost devoid of structural highs. Lowlands and wide plains characterized the landscape at the northern and eastern margins of the basin (Lavina, 1991).

The Irati Formation lies between the Palermo and Serra Alta formations and is delimited by regional discordances and local diastems (Holz et al., 2010a; Warren et al., 2015). On the basis of SHRIMP U-Pb dating of igneous zircons in volcanic ash beds, a ${ }^{206} \mathrm{~Pb} /{ }^{238} \mathrm{U}$ age of $278.4 \pm 2.2 \mathrm{Ma}$ is suggested for the basal portion of the Irati Formation, indicating an Artinskian depositional age (Cisuralian epoch) (Santos et al., 2006). However, SHRIMP U-Pb zircon ages from bentonite beds suggest a Kungurian age for the upper portion of the Irati Formation. The unit is $\sim 60 \mathrm{~m}$ thick and has a notorious basin-wide distribution of approximately 4 million $\mathrm{km}^{2}$ in the Brazilian Paraná Basin and African basins (Limarino et al., 2014). This unit extended from Uruguay (Mangrullo Formation, Delaney and Goni, 1963; Mones and Figueiras, 1981; Martinez, 2004), Paraguay (Beder, 1923; Harrington, 1956) and Brazil (Oelofsen and Araújo, 1983) into Africa, and encompassed the Artinskian Huab Formation, and Huab Basin in NW Namíbia, and the Whitehill Formation, the Ecca Group, and the Main Karoo Basin in South Africa (Padula, 1968; Araújo, 1976; Oelofsen and Araújo, 1987; Stollhofen et al., 2000) (Fig. 3). Therefore, the unit is a key stratigraphic datum that is traditionally used to divide the upper portion of the late 


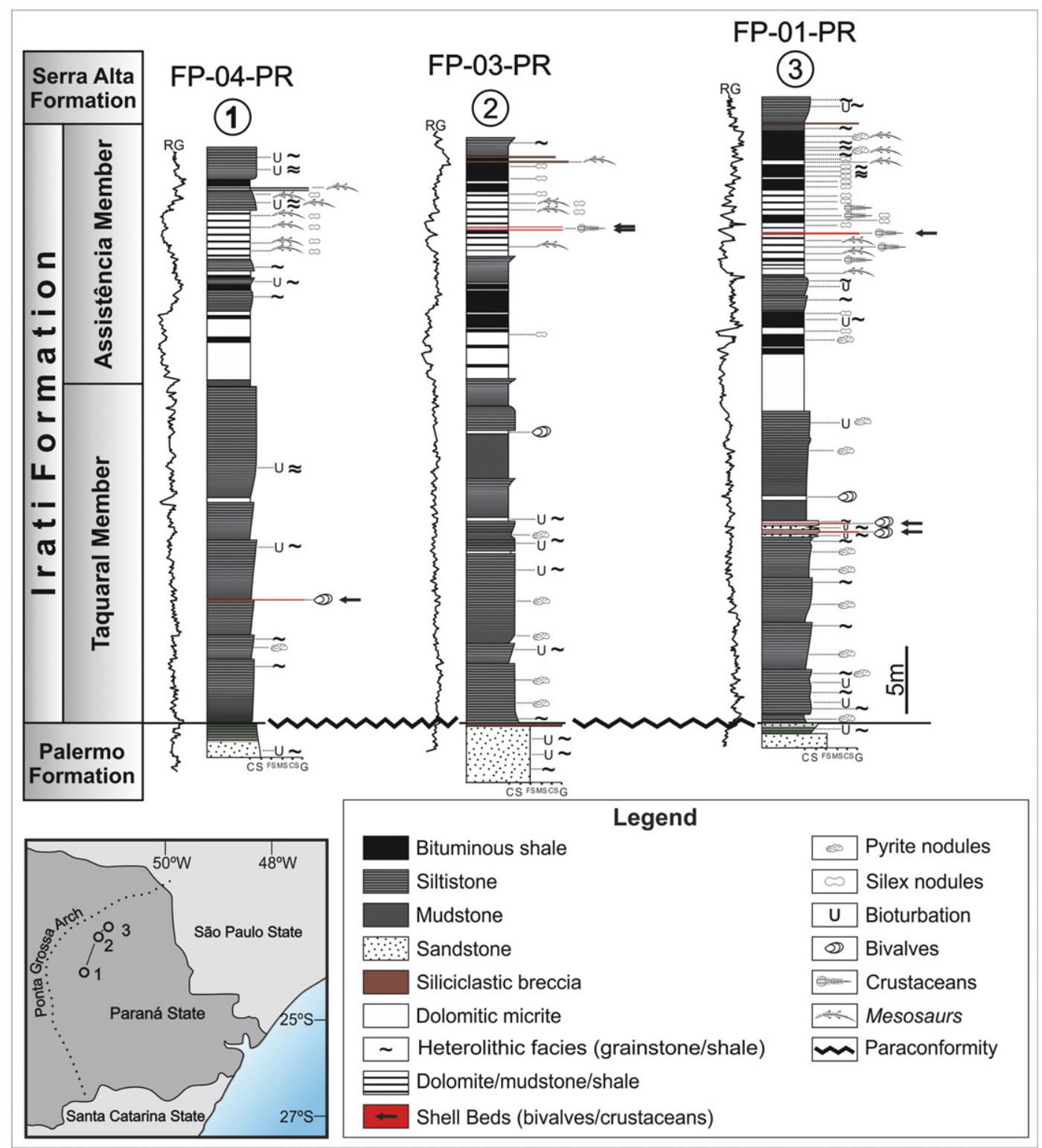

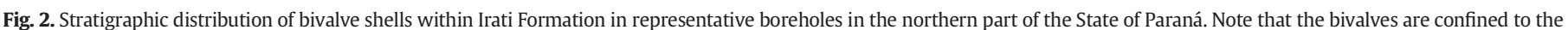

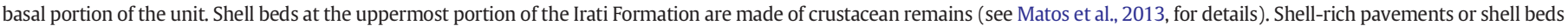
are indicated by arrows.

Modified from Lages (2004), Rohn (2007) and Holz et al. (2010a).

Paleozoic succession of the Paraná Basin (Gondwana I Supersequence, Milani et al., 2007) into two main lithostratigraphic units, the underlying Guatá (Rio Bonito and Palermo Formations) and Passa Dois (Serra Alta, Teresina, Rio do Rasto Formations) groups (Fig. 4).

Abundant organic-rich shales and mudstones characterize the basal portion of the unit (Taquaral Member), while claystones and siltstones are intercalated with tabular beds of dolomitic limestones towards the top (Assistência Member) (Schneider et al., 1974; Araújo et al., 2001; Hachiro et al., 1993; Hachiro, 1996). Regionally, the amount of carbonate facies increases from south to north. Hence, in the State of São Paulo, the Irati Formation consists of a rhythmic alternation of dolomitic limestones and oil-rich shales (Almeida and Barbosa, 1953; Mendes, 1967; Amaral, 1971; Hachiro et al., 1993; Hachiro, 1996). The cyclic alternation of dry and humid periods coupled with high-frequency sealevel changes driven by Milankovitch orbital variations are inferred to be the main factors favoring the genesis of the dolomite-bituminous shale alternations (Hachiro et al., 1993; Hachiro, 1996; Holz et al., 2010a). Nevertheless, the almost rhythmic successions of the
Assistência Member, the presence of articulated skeletons of endemic, aquatic mesosaurid reptiles, some with preserved soft parts (Rösler, 1974; Rösler and Tatizana, 1985), the occurrence of insects (e.g., Rösler et al., 1981) and crustacean remains (Caires, 2005; Ricardi-Branco et al., 2008), also exhibiting preserved soft-part molds (Matos et al., 2013), indicate that the deposition occurred predominantly under hypersaline (Piñeiro et al., 2012a, 2012b), quiet and oxygendepleted waters just at or below the storm-wave base (Hachiro, 1991, 1996). On the other hand, grainstone facies with meter-scale, hummocky cross-stratifications, centimeter thick-bone beds and crustacean-dominated shell beds suggest that the quiet muddy bottoms were occasionally disrupted by episodic, high-energy depositional events (i.e., storms) (Lavina et al., 1991; Soares, 2003; Matos et al., 2013). The abrupt replacement of siltstones, mudstones and shales of the Taquaral Member by the limestones of the Assistência Member are definitive evidence that the basin was progressively shallower (i.e., from an exclusively siliciclastic to a mixed carbonate-siliciclastic setting, Holz et al., 2010a). 


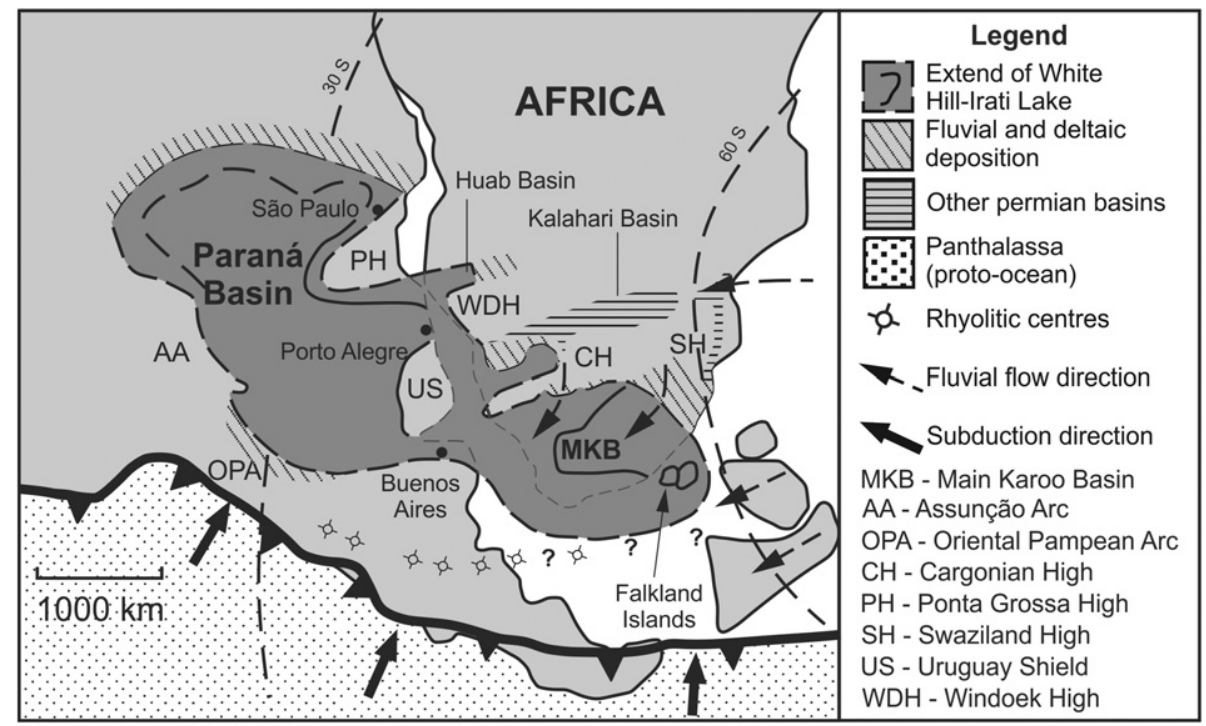

Fig. 3. Paleogeographic map of the central Gondwana region (South America, Namibia and South Africa), showing the main flooded areas during the Irati anoxic event. Modified from Faure and Cole (1999).

There is no doubt that part of the Irati Formation could have formed during a period of widespread stagnation of the bottom waters of the Paraná Basin (see Runnegar and Newell, 1971). Abundant bitumen, pyrite, and kerogen, together with the almost complete absence of benthic invertebrate trace fossils, suggest that the shales and much of the distal carbonates were deposited under dysoxic to anoxic conditions (Amaral, 1971; Subacius and Amaral, 1983; Maynard et al., 1996; Hachiro, 1996; Faure and Cole, 1999; Calça and Fairchild, 2012). Concomitantly, the climate was interpreted as seasonal, with dry summers and rainy winters (Monteiro, 1979; Mussa et al., 1980; Costa, 1981; Alves, 1994). However, the very recent contributions of Euzébio et al. (2016), and Goldberg and Humayun (2016) demonstrated a much complex paleoenvironmental scenario for the deposition of the shales of this unit. Geochemical paleoredox indicators (redox-sensitive elements, DOPT and $\mathrm{Fe}_{\mathrm{T}} / \mathrm{Al}$ ), from 43 drill-core samples of the Irati Formation from the southern part of the Paraná Basin indicate that the bottom waters were not persistently anoxic, but rather oxygen concentrations varied significantly during deposition of the formation (Goldberg and Humayun, 2016, see also Euzébio et al., 2016). According to Goldberg and Humayun (2016), periods of episodic ventilation are also indicated by sedimentologic evidences (e.g., interbedded calcarenites with hummocky cross-stratification, silty laminae with small ripples, and bioclastic lag laminae). To those authors, the Irati Formation was deposited in a salinity-stratified body of water, mainly under dysoxic to oxic conditions (i.e., anoxic conditions were episodically). Indeed, traceelements indicate that the black shales were similar to "average" silty shales, except in two intervals where the rocks are enriched in U (two to five times) and Mo (four to five times), suggesting fully anoxic conditions (Goldberg and Humayun, 2016). These are $<10$-m thick intervals also displaying very high $\mathrm{Fe}_{\mathrm{T}} / \mathrm{Al}$. The positive correlation between $\mathrm{Cu}$ and $\mathrm{Cu} / \mathrm{Mo}$ ratio suggests that bottom-water anoxia was driven by increased organic flux, probably from algal blooms (Goldberg and Humayun, 2016, see also Araújo, 2001). In this way, increased productivity resulted from the nutrient input via high continental runoff to the landlocked sea, which was mainly located in the mid-latitude humid zone (Goldberg and Humayun, 2016).

\section{Geological setting}

In the study area, the Irati Formation comprises a narrow NW-SE strip that surrounds the eastern flanks of the hills in the vicinity of the homonymous city, State of Paraná, Brazil (Fig. 4). The best outcrops are in active and abandoned quarries (Table 1 ) where complete sections up to $30 \mathrm{~m}$ thick occur. In the central and southern portions of Paraná State, the Irati Formation comprises a thin ( $<60$ m thick) succession composed of black shales and dark-grey silty shales occasionally interbedded with tabular, centimeter-thick carbonate layers. The presence of euhedral pyrite crystals in the pelitic beds indicates that sedimentation and eodiagenesis occurred under reducing conditions. Centimeter-scale nodular arsenopyrite and sphaeroidal septarian carbonate concretions disseminated in the rock are quite common. The Irati Formation occurs in erosive contact above the green pelites of the Middle Artinskian Palermo Formation (Holz et al., 2010a) and immediately below the grey siltstones of the Serra Alta Formation (Fig. 4).

Detailed stratigraphic sections were acquired in two quarries located north of Irati City and approximately $7 \mathrm{~km}$ from each other (Figs. 5, 6, 7). The studied succession is approximately $15 \mathrm{~m}$ and is stratigraphically located above the paraconformity separating it from the underlying Palermo Formation and the corresponding basal portion of the Irati Formation (Taquaral Member) (Fig. 4). Sections A and B are both mainly composed of dark pelitic facies as shale and silty shales, with subordinated grainstones at the top. The lower portion of the succession is marked by the presence of nodular, centimetric, septarian arsenopyrite concretions dispersed in the rock. These nodules appear to have been formed by progressive cementation from the centers to the rims; they show no internal deformation, suggesting that they are eodiagenetic (Mozley, 1996). The occurrence of several examples of plastic deformation of the shales around the nodules reinforces the hypothesis of a precompactional origin. At the middle portion of the succession, decimetric spheroidal carbonate concretions are also common and confined to a meter-scale layer. Fossils include insects, plants, Clarkecaris crustaceans and fish remains (scales and teeth) dispersed in the pelitic matrix.

The apparently monotonous succession is composed of dark pelites (Figs. 5, 6A-C) organized in three metric cycles and characterized by subtle changes in grain size, from shales at the base to silty shales at the top, Fig. 5 . The variation in grain size is indicated by the differential erosion profile in the silty shales located at the top of the cycles and by the presence of quartz silt grains dispersed in the very fine pelitic matrix, which was confirmed by petrographic analysis. The upwardcoarsening cycles are marked by the occurrence of fossiliferous beds at the top, as observed at the upper portion of the cycle 1 (Fig. 5). These beds are laterally continuous and form millimeter-thick pavements 


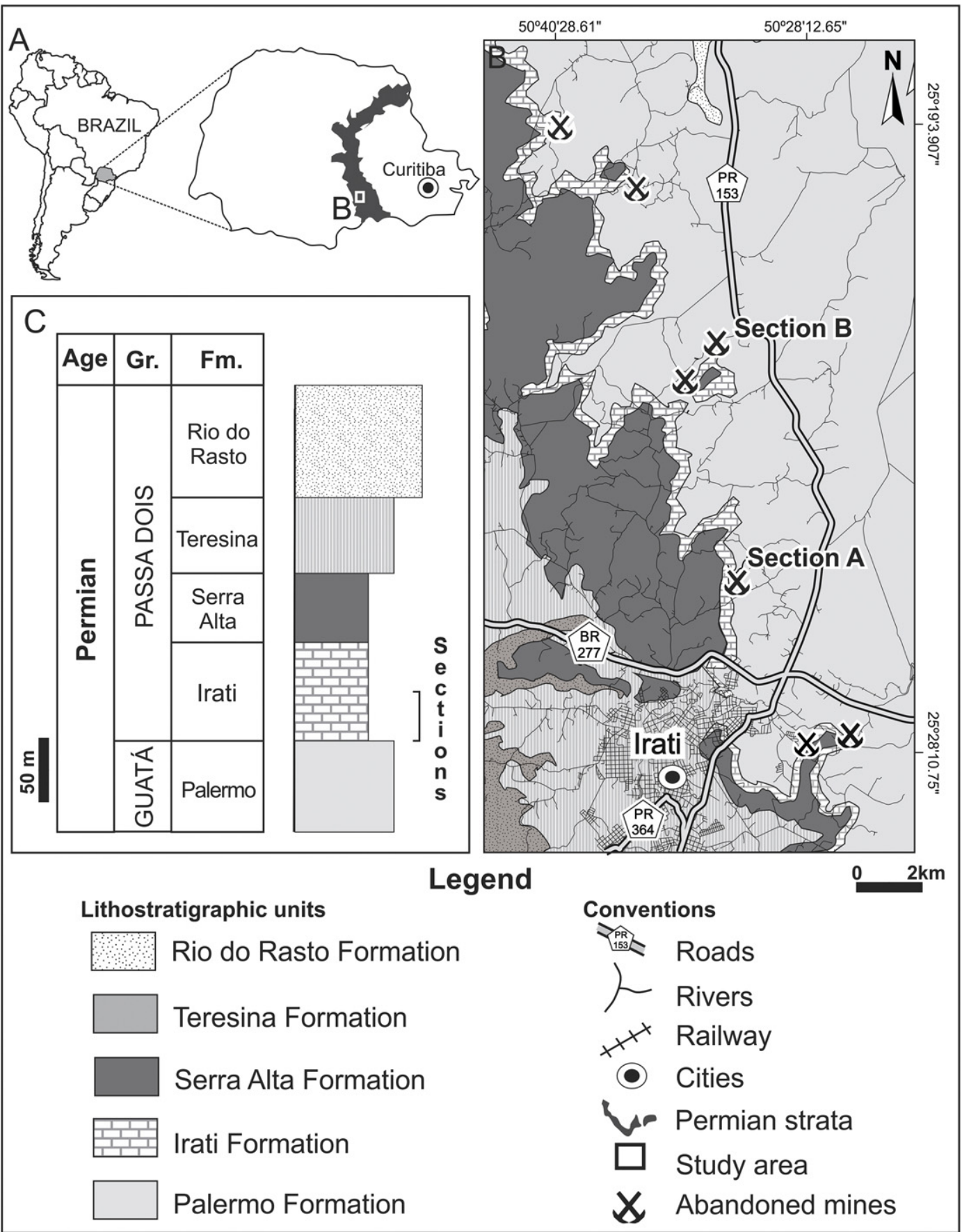

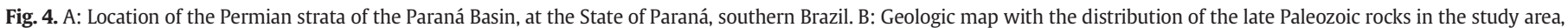
showing the location of the columnar sections. C: Schematic lithostratigraphic column of the Permian Guatá and Passa Dois Groups.

Source of data: MINEROPAR (2006)

Table 1

Locations and conditions of the bivalve-rich quarries of the Irati Formation, Taquaral Member, near the city of Irati-PR (UTM Zone J).

\begin{tabular}{llll}
\hline Quarry & Location (UTMs) & Access & Observations \\
\hline I & $7.182 .595 \mathrm{~m} \mathrm{~S} / 538.866 \mathrm{~m} \mathrm{E}$ & Private, closed & \\
II & $7.183 .165 \mathrm{~m} \mathrm{~S} / 540.376 \mathrm{~m} \mathrm{E}$ & Private, closed & Partially flooded \\
III & $7.186 .932 \mathrm{~m} \mathrm{~S} / 537.035 \mathrm{~m} \mathrm{E}$ & Private, open & Abandoned \\
IV & $7.193 .653 \mathrm{~m} \mathrm{~S} / 536.388 \mathrm{~m} \mathrm{E}$ & Private, open & Partially active \\
V & $7.193 .001 \mathrm{~m} \mathrm{~S} / 535.454 \mathrm{~m} \mathrm{E}$ & Private, open & Abandoned, flooded \\
VI & $7.197 .784 \mathrm{~m} \mathrm{~S} / 534.214 \mathrm{~m} \mathrm{E}$ & Private, open & Abandoned \\
\hline
\end{tabular}

consisting of small fragments of disarticulated bivalve shells. At the top of cycle 1 , several bioclastic-rich beds occur interbedded with a shale layer constituting a decimetric rhythmic succession of fossiliferous and non-fossiliferous levels.

\section{Materials and methods}

At the study area (Fig. 4), the basal portion of the Irati Formation was analyzed and columnar sections were acquired (Figs. 5, 6, 7). In the field, particular attention was given to the vertical distribution, geometry and 


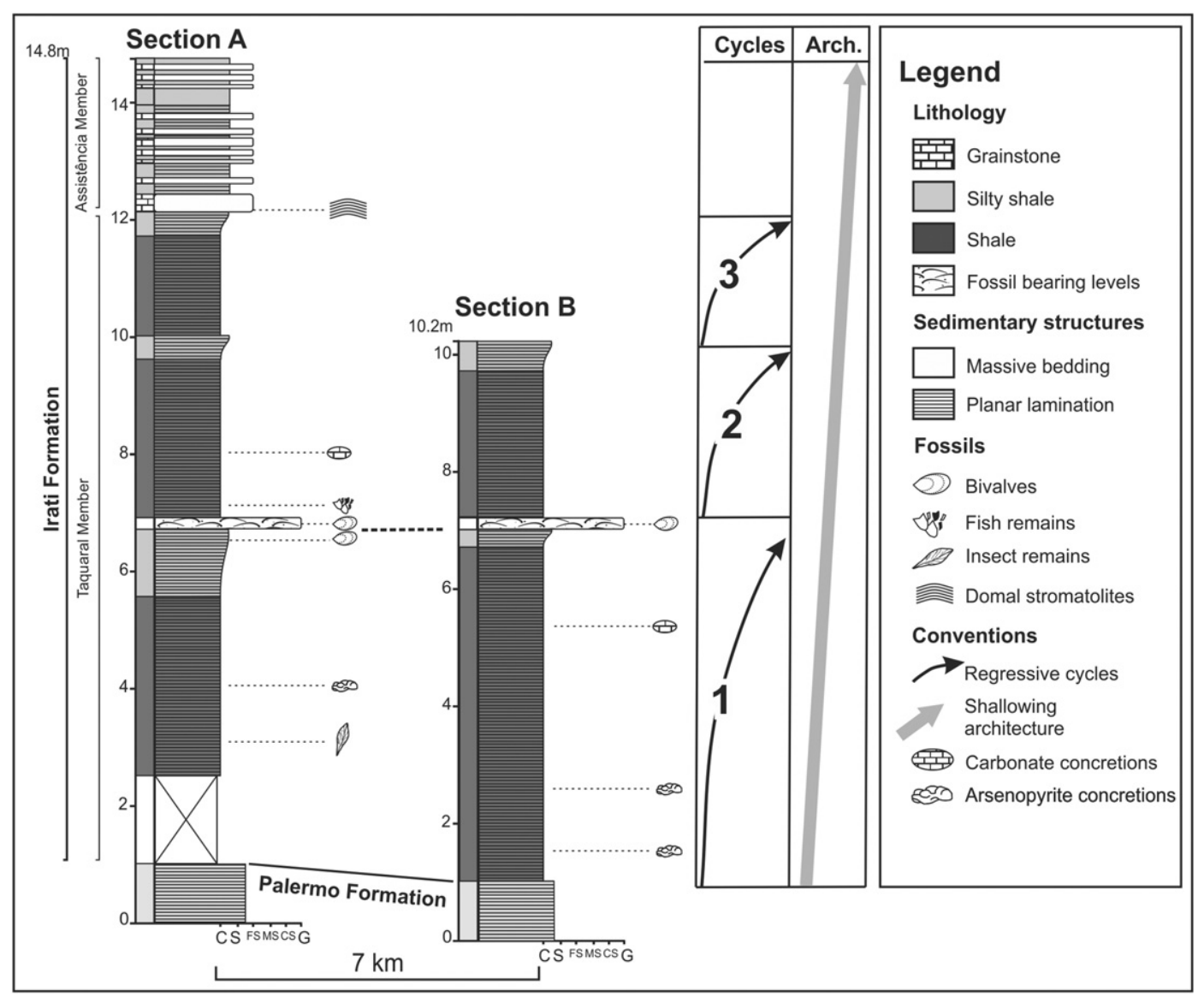

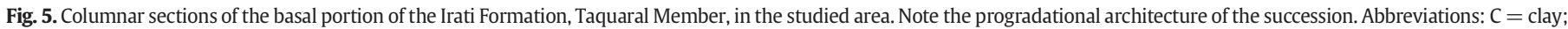
$\mathrm{S}=$ silt; $\mathrm{FS}=$ fine sand; $\mathrm{MS}=$ medium sand; $\mathrm{CS}=$ coarse sand; $\mathrm{G}=$ granule.

stratigraphic contacts of the shell-host rocks and shell concentrations. The biofabric (sensu Fürsich and Oschmann, 1993), shell-size sorting, and orientation (plan and cross-sectional views), valve articulation and fragmentation were quantitatively measured (e.g., Kidwell et al., 1986; Kidwell, 1991; Kidwell and Holland, 1991; Fürsich and Oschmann, 1993) (Figs. 8, 9). The shell abundance (the degree of cover, sensu Posenato et al., 2013, p. 266) in the pavements was also quantitatively measured, which ranged from sparse (2-5 valves per $20 \mathrm{~cm}^{2}$ ) to dense (surface totally covered by valves). In addition to the information directly acquired in the field, several rock slabs were taken to the laboratory for thin-sectioning and taxonomic analysis. The rose diagrams in Fig. 9 show the frequency of shells in a given orientation perpendicular to the paleoflow. Since some samples are falling slabs, all rose diagrams were rotated to adjust the values with high frequencies to the N-S direction. The slabs are deposited in the paleontological collection of the Institute of Biosciences, São Paulo State University, under the code DZP.

Most of the shells in the pavements are extremely compacted, and were thus counted in thin sections to determine the degree of valve articulation. The bivalves were identified only to generic level since the shells are usually compressed and poorly preserved. In fact, various features make the precise classification of the shells at the species level difficult, including (a) the compactional distortion of shells and (b) the lack of preserved internal characters such as muscle scars and hinge structures. The identification of the shells was mostly based on Mendes (1952), Runnegar and Newell (1971), Simões and Anelli (1995), and Simões et al. (1997).

\section{Results}

\subsection{Taphonomy}

In the studied succession of the Irati Formation (Figs. 5, 6, 7) (1), a fossil-poor mudstone and (2) shell-rich pavements are both characterized by the presence of small $(\mathrm{mm})$ bivalves. The first includes a relatively barren mudstone with minute, complete shells of Runnegariella, Plesiocyprinella and other unidentifiable bivalves. The valves are chaotically oriented in a massive mudstone (Fig. 8E) in which the shell density varies laterally from barren to dispersed (sensu Kidwell et al., 1986). The specimens are disarticulated and fragmented shells, with abundant shell debris. Signs of post-depositional deformation/ fragmentation of the shells are usually present. The most conspicuous occurrence of this mudstone lithotype is $\sim 56 \mathrm{~cm}$ below the first shell pavement in the succession (Figs. 5, 7C), where it forms a layer $10-15 \mathrm{~cm}$ thick.

On the other hand, mono- to paucispecific shell pavements are locally the most conspicuous fossil-rich lithotypes in the first half of the investigated interval of the Irati Formation (Figs. 5, 6D-E, 8). The beds with the pavements are $\sim 30 \mathrm{~cm}$ thick (Fig. 6 ) and each individual pavement is $<1-2 \mathrm{~mm}$ thick (Fig. 6D-E). The shell covering is dense and each pavement is separated only by $\sim 1-5 \mathrm{~mm}$ of shell-poor or barren mudstones (Fig. 6D-E). At least 32 thin-shell pavements were counted in this interval at the section in Quarry A (Figs. 4, 6). However, at other outcrops in the study area, Kazubek and Simões (2003b) counted at least 270 shell pavements in an interval $52 \mathrm{~cm}$ thick. 

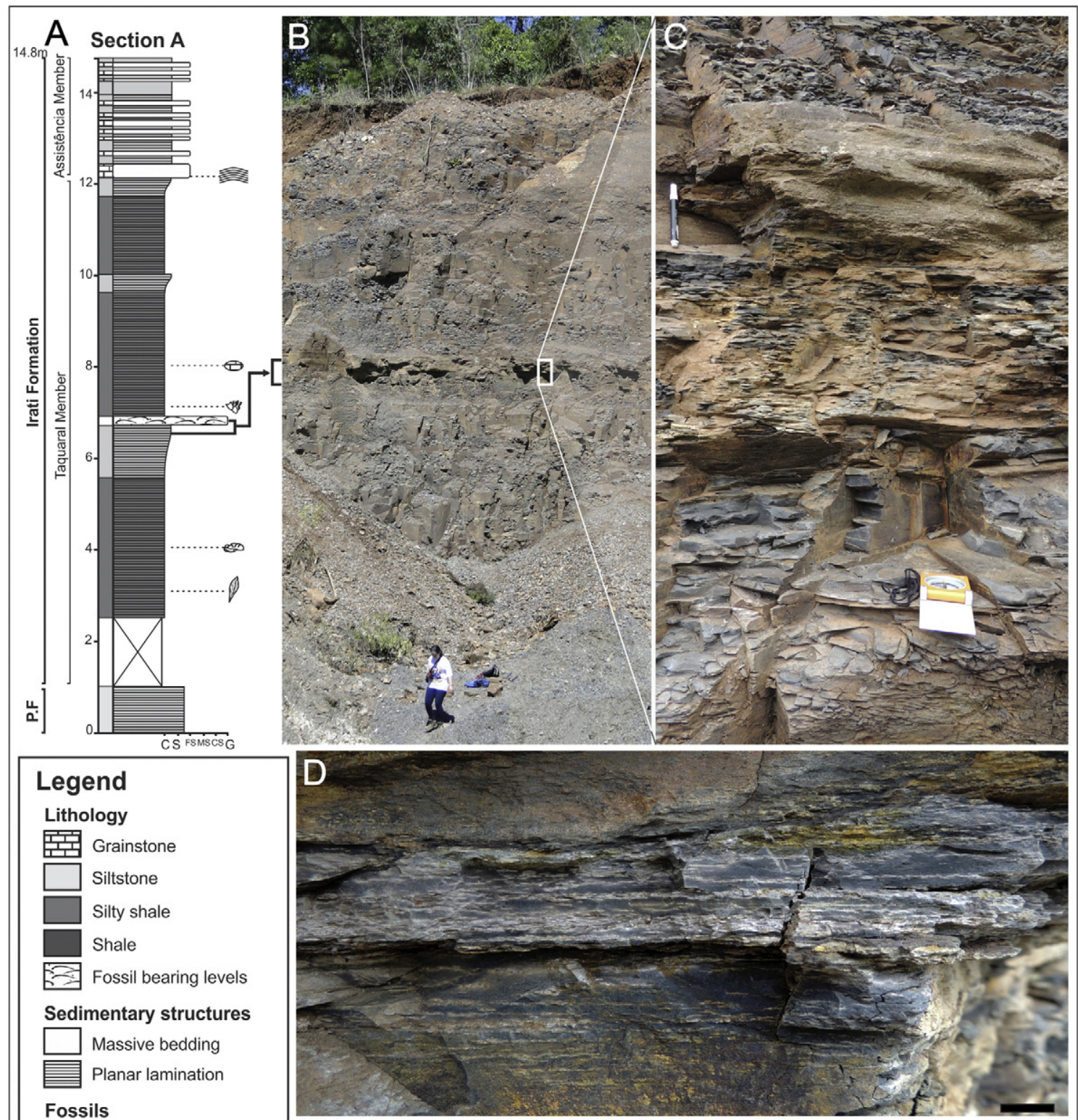

Sedimentary structures

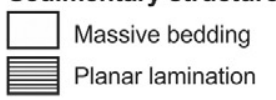

Fossils

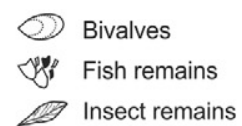

$\$$ Insect remains

\section{Conventions}

Carbonate concretions

Arsenopyrite concretions

Stromatolites

\section{E}

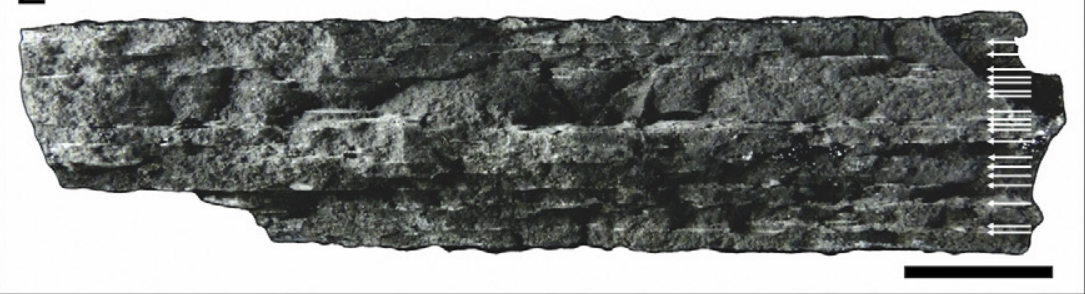

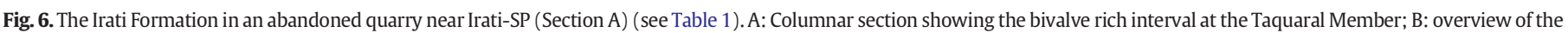

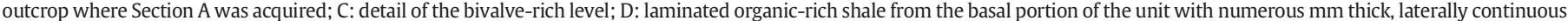

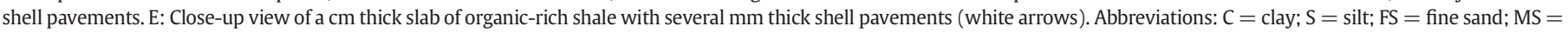
medium sand; $\mathrm{CS}=$ coarse sand; $\mathrm{G}=$ granule. $S$ cales $=1 \mathrm{~cm}$.

The base of each individual pavement is usually sharp (Fig. 6E-D) and undulated, and the pavements are covered by complete, disarticulated shells of infaunal bivalves. The shells occur in high densities on various bedding planes and left valves always predominate (see Figs. 6, 8, 9). Evidence of bioerosion and encrustation is lacking. In all bedding planes studied, the shells are mainly in a convex-up orientation, which can be seen in thin sections (Figs. 8, 9, 10 see also Kazubek and Simões, 2003b). Measurements of a number of shell molds preserved in the pavements (fallen slabs) showed a preferred orientation (Fig. 9). Size-frequency histograms of shells from individual pavements commonly show a unimodal or bimodal distribution (Fig. 9). Additionally, comminuted and rounded shell debris occur associated with whole valves in some pavements. Sometimes debris can form millimeter-thick laminae just above the pavements. 


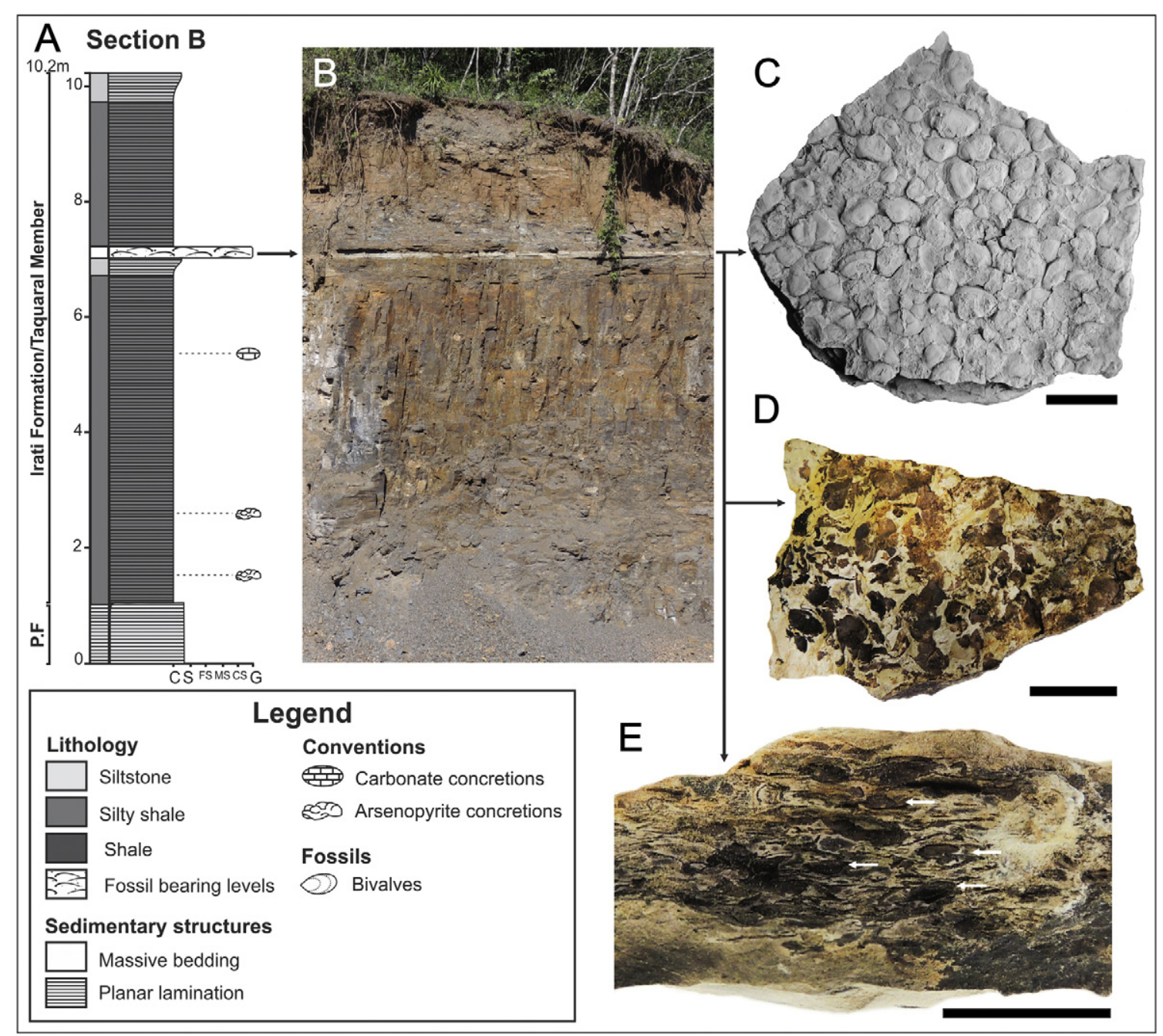

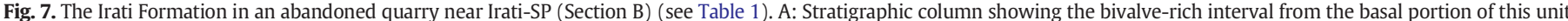

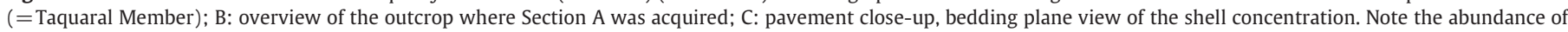

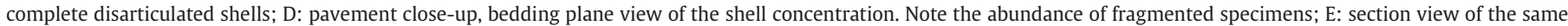
sample in D. Scales $=1 \mathrm{~cm}$.

\subsection{Faunal composition}

The shells in the pavements are densely packed and it is difficult to split some of them apart. The shells are poorly preserved with no signs of muscle scars or hinge structures (teeth and sockets), which prevents their accurate identification. However, in the mudstones below the shell pavements, the bioclasts are loosely packed and relatively well-preserved shells can be found. At least two genera are represented: A-Runnegariella is a small (maximum length $=9.9 \mathrm{~mm}$ ) infaunal, shallow, facultatively mobile, suspension-feeding bivalve. Closed articulated shells of species of this genus (e.g., $R$. fragilis) are recorded in micritic limestones generated in shallow-water conditions in the Teresina Formation (Simões and Anelli, 1995) (Fig. 11). B-Plesiocyprinella is also an infaunal, shallow, facultatively mobile, suspension-feeding bivalve. Actually, this is one of the most abundant components of the bivalve assemblages of the Teresina/Corumbataí formations (see Simões and Kowalewski, 1998) (Fig. 11). In situ shells of Plesiocyprinella are commonly found in bioclastic sandstones of this unit. Hence, the composition of the studied assemblage is noteworthy, since the fauna includes a large amount of unidentified specimens (in some cases poorly preserved and broken shells) associated with shallow burrowing forms referred to common taxa in the basal and middle portions of the Teresina Formation.

\section{Discussion}

6.1. Are the shells in the offshore mudstones autochthonous, parautochthonous or allochthonous?

Bivalves are common and are the dominant benthic elements in the shallow-water paleocommunities of the Permian Passa Dois Group in the Paraná Basin, Brazil (Runnegar and Newell, 1971; Simões et al., $1998,2015)$. Within this unit the bivalve occurrences are grouped in distinct assemblages, which are arranged in ascending order (Fig. 1). They are extremely common in the proximal and very rare in the distal facies (but see Bondioli et al., 2015 and Warren et al., 2015 for exceptions). For example, until now, only Maackia iratiensis was reported from the oil-rich mudstones of the Irati Formation on the basis of just one specimen (Beurlen, 1957b). Hence, the occurrence of tiny shells of shallow burrowing bivalves (e.g., Runnegariella and Plesiocyprinella) in the oxygen-deficient facies of the Irati Formation is unique within this unit (Fig. 11). A possible explanation for the presence of these bivalves is that they are autochthonous elements and may represent a mortality of individuals that briefly colonized anoxic-dysoxic substrates (see Oschmann, 1991; Wignall and Hallam, 1991; Fürsich et al., 2012, for examples). However, despite their burrowing mode of life and the high degree of cover $\left(2-5\right.$ shells $\left./ 20 \mathrm{~cm}^{2}\right)$, none of the shells was preserved 


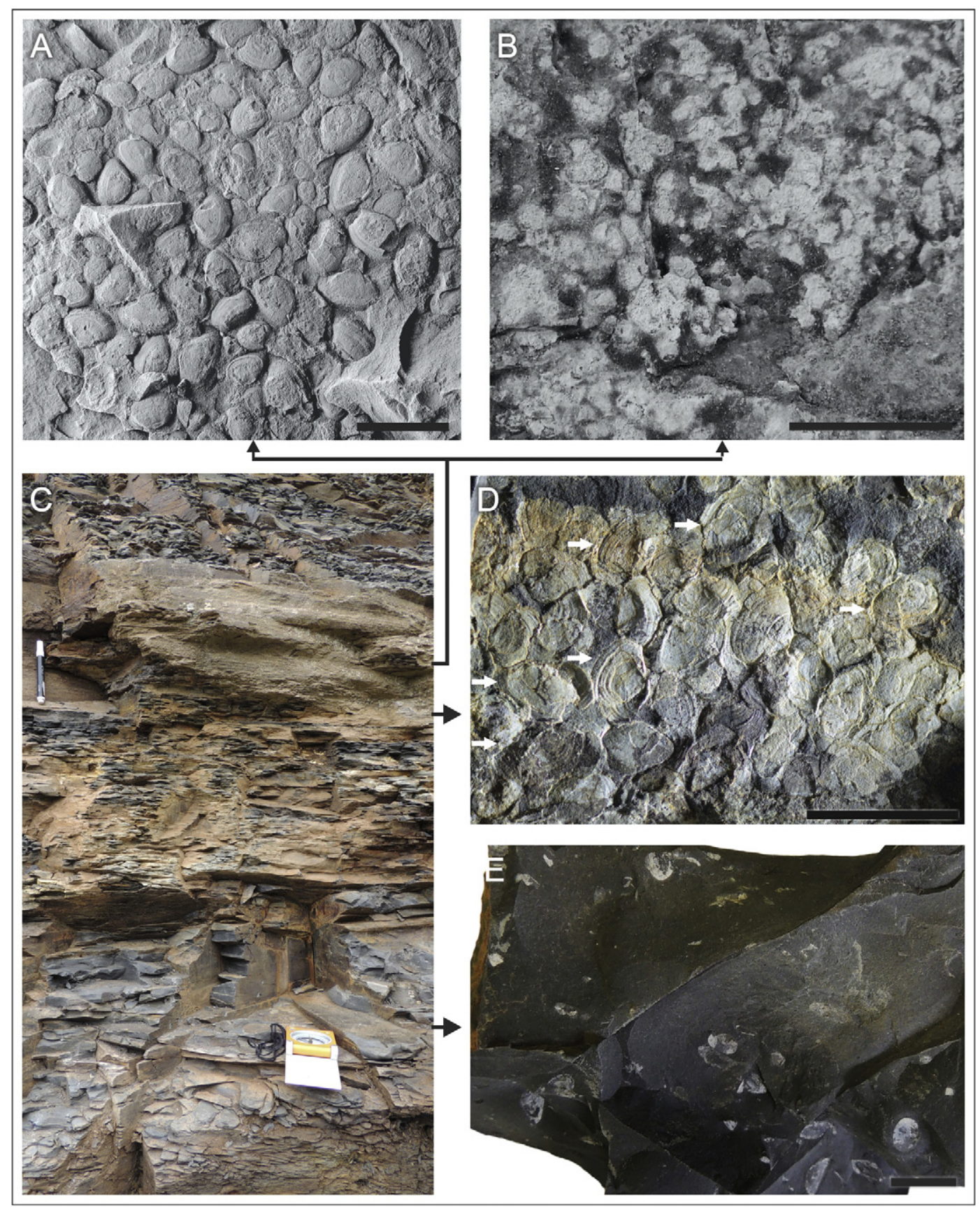

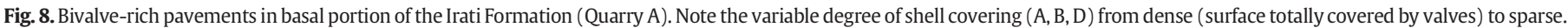

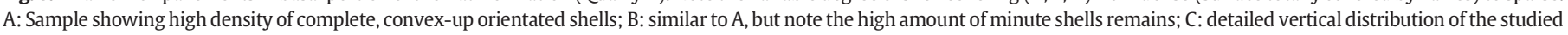

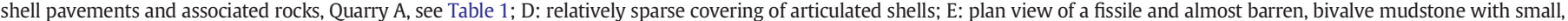
disperse and disarticulated, chaotically oriented bivalve shells. This fossil-poor interval is overlain by organic-rich shales with shell pavements.

in situ and evidence of intrastratal biological activity is lacking in the matrix. Hence, an intriguing question emerges, were those abundant shells and shell debris disrupted from their original substrate, partially reworked in shallow-water settings, and subsequently transported offshore (allochthonous shells in the sense of Kidwell et al., 1986)?

In pooling the data, bivalve shells are mainly represented by disarticulated valves $(94.30 \%, \mathrm{n}=364)$ and more rarely by articulated (closed $5.18 \%, \mathrm{n}=20$ or butterflied $0.52 \%, \mathrm{n}=2$ ) valves. Most of the shells are left valves $(60 \%, n=81)$, indicating a pronounced $50: 50$ (left-right) valve deviation, suggesting that the shells were differentially transported (see Chattopadhyay et al., 2013, and references therein). In those individual pavements where complete shells can be confidently measured, size-frequency histograms of the valves show unimodal or bimodal peaks (Fig. 9), indicating that the shells are well sorted. Tiny shell fragments $(>3 \mathrm{~mm}$ ), some rounded and others with sharp edges, are also very abundant in some levels, contrasting drastically with the prevailing quiet-water conditions during the deposition of the mudstones. These imply that part of the shell remains were mechanically fragmented in shallow water-facies, probably by background processes. Additionally, the presence of oversize grains (thousands of millimeter-size bivalve bioclasts) also contrasts with the depositional environment characterized by the deposition of mud in very calm conditions.

In summary, the above evidence indicates that the shells were transported from contemporary shallow-water facies and swept into the offshore muds. 


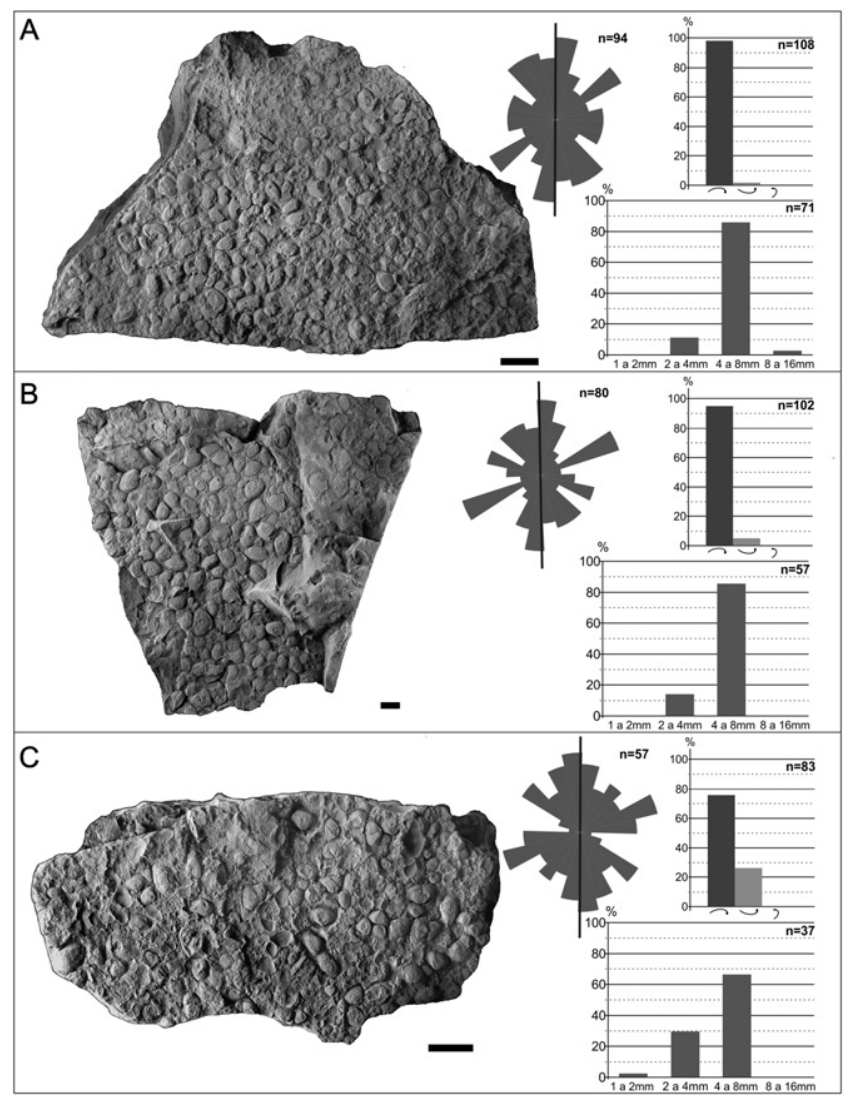

Fig. 9. Shell-pavements from fallen slabs DZP-19014 (A), DZP-19010 (B), DZP-19019 (C) showing the orientation of disarticulated shells on bedding planes of organic-rich shales of the Irati Formation. Rose diagram showing orientation of the shells; proportions of convex-up or -down valves and shell size sorting are exposed on the right.

\subsection{Genesis of the shell-rich bivalve pavements}

Bivalve shells are amazingly abundant in the approximately $1 \mathrm{~m}$ thick intervals of offshore mudstones. At least two distinct modes of shell concentrations are recognized from the base to the top of the succession, including (1) dispersed, chaotically oriented shells in massive mudstones, and (2) shell-rich pavements composed of complete shells or comminuted remains. In the first case, the bivalve shells are complete or fragmented and are exclusively represented by disarticulated valves (Fig. 8E). This suggests that they were scoured out from the original shallow water bottom by erosional processes (storm flows) and settled from suspension in the distal portions of the basin (Fig. 12). Hence, the entrainment of the shells in the sediments occurred without the subsequent action of long-lasting bottom currents (see also Posenato et al., 2013, for a similar example). In the second type of deposit, the shells are mainly single valves, but rare conjoined (closed, or butterflied, $5.7 \%, \mathrm{n}=22$ ) valves are also present. The pavements show an upward increase in the degree of valve abundance and shell fragmentation (Fig. 8). However, isolated shells (mainly left valves) predominate and are mixed together with articulated shells.

In the taphonomic analysis, the degree of mollusk shell articulation in a given assemblage is commonly used as a proxy for shell transportation and residence time at the sediment/water interface (Brett and Baird, 1986). However, various authors have shown that closed, articulated bivalve shells can be transported for long distances (Cadée, 2002). During transport, these animals may be alive (Sörliin, 1988; Hunt et al., 2007; Fürsich et al., 2016) or dead with dried tissues (Cadée, 2002). In our case study, we infer that the rare, tiny, closed articulated shells of shallow burrowing bivalves were transported alive, dying only at the inhospitable oxygen-deficient depositional setting. The bivalves died
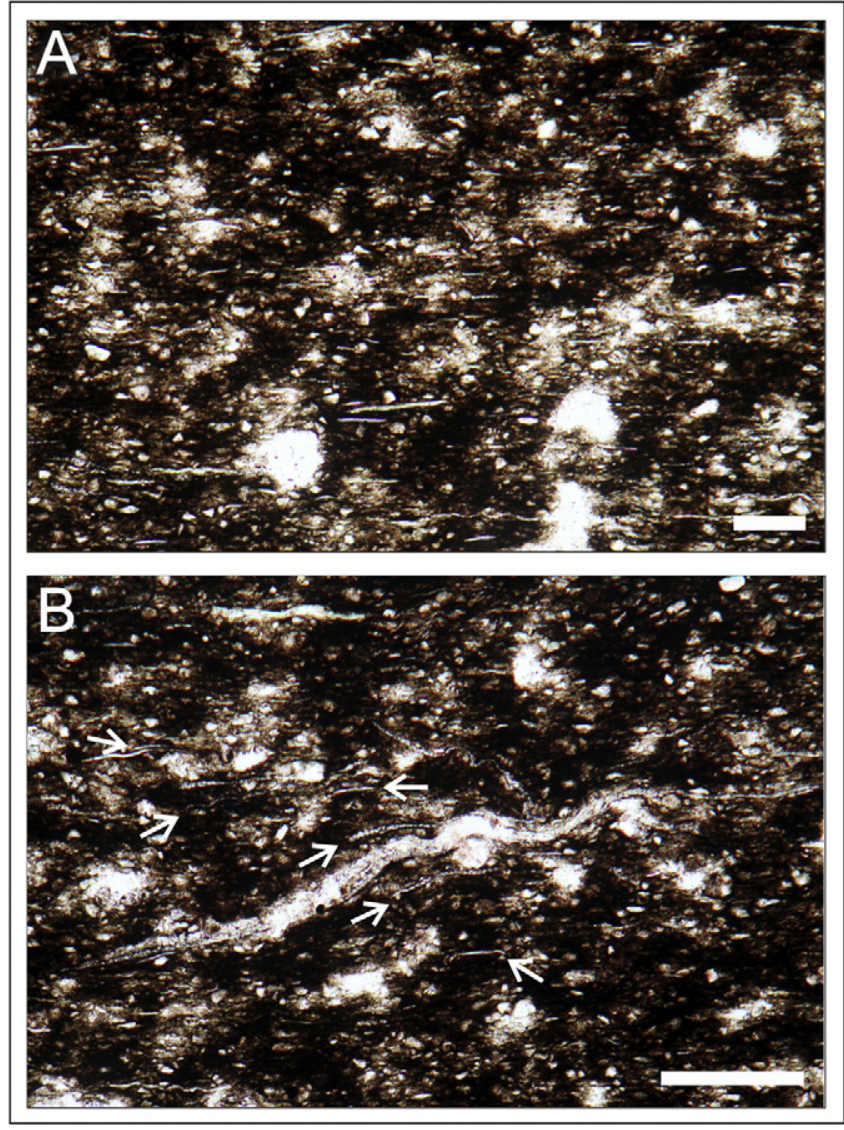

Fig. 10. Thin-sections showing the minute bivalves in shell-rich shales of the Irati Formation. A: Note the dense occurrence of the shells, which are almost flat due to compression. B: Bivalve shells in convex-up posture (arrowed). Graphic scale: $0.25 \mathrm{~mm}$.

without trying to re-burrow themselves, since the shells are preserved concordant to the bedding and the sediments are not disrupted (see Fürsich et al., 2016, for a similar example).

The preservation of articulated (butterfly) shells in the pavements may indicate different scenarios, but it is highly unlikely that previously splayed (butterflied) shells could have been transported articulated for long distances (see also Allmon, 1985; Selover et al., 2005). They may represent recently dead and closed articulated bivalves in shallowwater settings, which gaped during transport (see Watkins, 1974). Alternatively, they may represent transported individuals that died soon after deposition in the offshore muds (see above) and were exposed for short periods of time in the sediment/water interface prior to final burial. In all, those rare articulated (closed or splayed) bivalve shells are not autochthonous in the studied deposits. Finally, gaped shells often occur in fine-grained, non-bioturbated sediments generated under anoxic to dysoxic conditions, which favor the slow decay of the ligaments (Plotnick, 1986; Allison and Briggs, 1991). Indeed, some authors (Etter, 1996; Schatz, 2005) have shown that butterflied bivalve shells are commonly found in sedimentary facies associated with severely dysoxic bottoms in low-energy settings (e.g., Oschmann, 1991; Wignall and Hallam, 1991). As discussed above, all these conditions were common in the environment of the Irati Formation where the shell-rich pavements were deposited. However, should be noted that both disarticulated and articulated shells were preserved with their commissural plane concordant to the bedding and predominantly in a convex-up orientation (Fig. 9). These observations imply that after settling down, the shells were submitted to persistent bottom currents that overturned them to the stable, convex-up orientation. The measured directions of hundreds of shells from individual slabs showed pavements with specimens in preferred orientation, which is perpendicular to the 

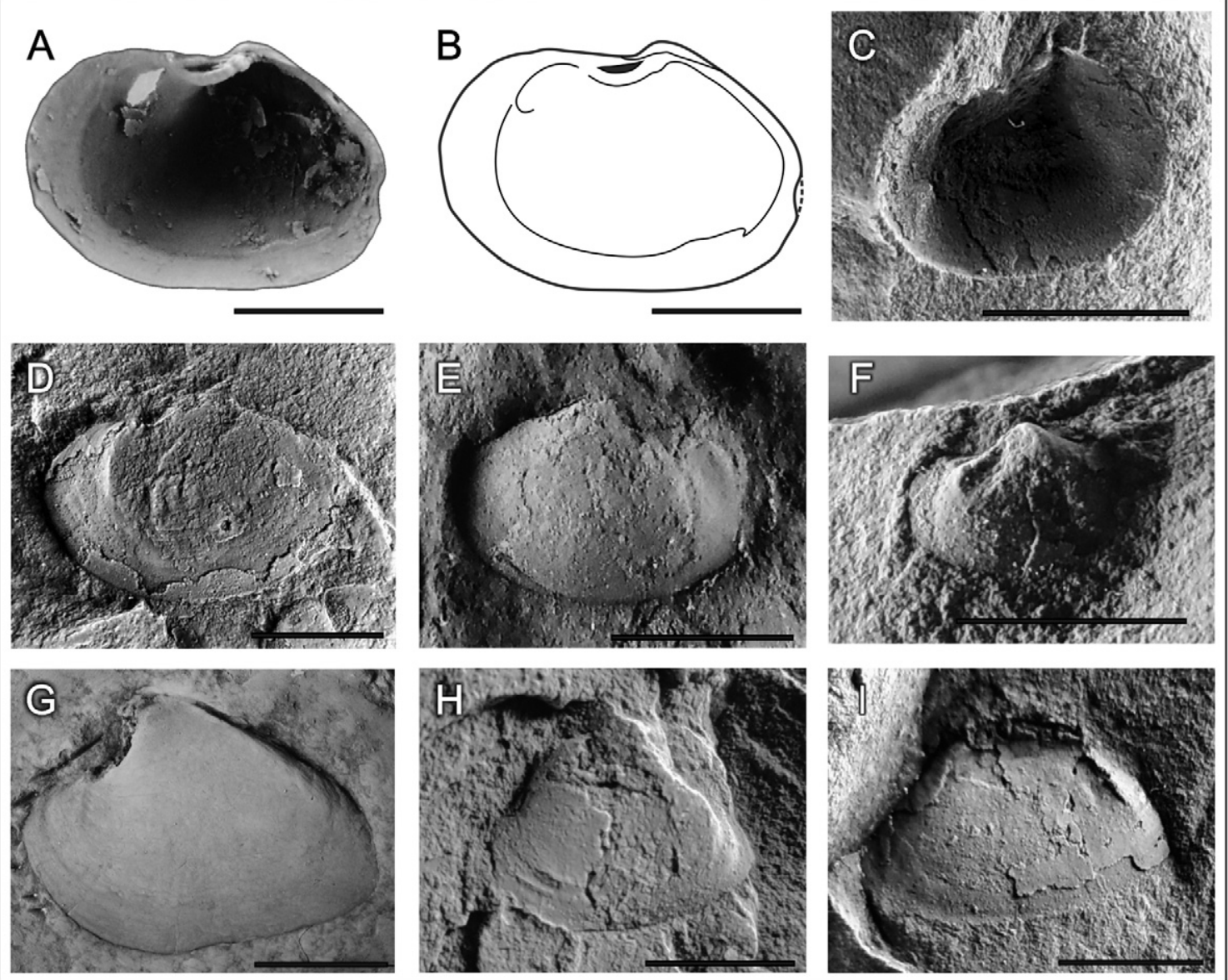

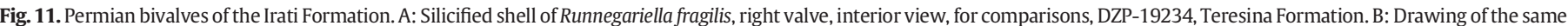

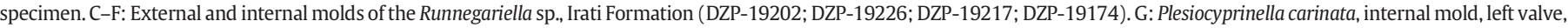

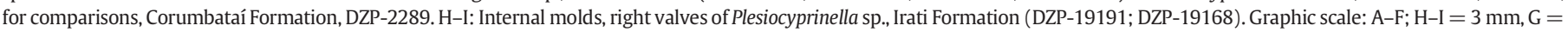
$10 \mathrm{~mm}$.

directions of the bottom currents (Fig. 9). In other words, despite the generally calm background conditions that prevailed during the deposition of the pelitic facies in the studied stratigraphic interval, the bottom currents affected the basin floor. Indeed, the sharp and undulated base of each individual shell-rich pavement indicates bottom erosion prior to the final deposition.

Finally, some pavements are made-up only of comminuted shell debris (Fig. 8B). Some fragments exhibit sharp margins while others are rounded. Hence, the shelly remains show distinct taphonomic pathways, all incompatible with the calm conditions prevailing in the depositional setting. They may represent bioclasts that were differentially reworked in shallow water-settings after being transported offshore in the water column by high-energy combined flows during storms. After the storm event, the fine-grained bioclasts were deposited by suspension fall-out. In summary, the bivalve-rich pavements of the Irati Formation are the final product of combined sedimentary processes, including high-energy episodic events (storm flows), followed by the action of background agents (long-lasting shelf currents) in an oxygen-deficient, low-energy offshore setting.

\subsection{An alternative genetic model for the origin of the Irati shell-beds}

An alternative explanation for the origin of the shell fragments found in the shell-rich deposits described above is that the valves were biomechanically fragmented by durophagy in shallow water settings and latter transported to distal settings in a similar manner of those found in Late Triassic shell-beds (Zogno 2) in mudstones of the Lombardian Basin, northern Italy (see Tintori, 1995). There, storm waves reworked loose bivalve shell fragments derived from fish-predation, which were later transported by turbidite currents to the anoxic bottoms of the distal parts of the basin (Tintori, 1995). Hence, the generated shell-beds in mudstones are mainly formed by biomechanically fragmented shells (Tintori, 1995). Despite the fact that vertebrates (Xenacanthiformes, Ctenacanthiformes, Petalodontiformes, Actinopterygii, Sarcopterygii, Tetrapodomorpha.) are common in sandstone beds of the base of the Taquaral Member of the Irati Formation (Chahud and Petri, 2015), fish remains were not found in the studied succession. In addition, predatory trace (i.e., semicircular notches on the fragmented edges or punctures on whole valves, see Tintori, 1995) are lacking in the bivalve shells. Hence, there is no any evidence of predation by crushing or drilling on the shells, and these processes are unlike to be the main culprit for bivalve shell fragmentation.

In the Italian Triassic Riva di Solto shales, there are also dense paucispecific shell-beds (Member 2) of infaunal and semi-infaunal bivalves that are in anoxic distal-type deposits (Tintori, 1995). These are similar to the bivalve shell pavements of the Irati Formation. However, the shell-beds are thought to be concentrated by stormwave winnowing of fine-grained sediments, which concentrate living or recently dead shells in place. Hence, the Riva di Solto shells are often articulated (Tintori, 1995). As in the case of the Irati Formation, no burrows are associated with those shells (Tintori, 1995). Contrary of the Italian shells, the Irati ones are mostly disarticulated and not fragmented. The predominance of some size classes, the high degree of shell disarticulation, strong valve type bias and the dominance of shells in convex-up posture are all indicative of bioclast transport rather than a local rework of living shells in fine-grained distal bottoms. 


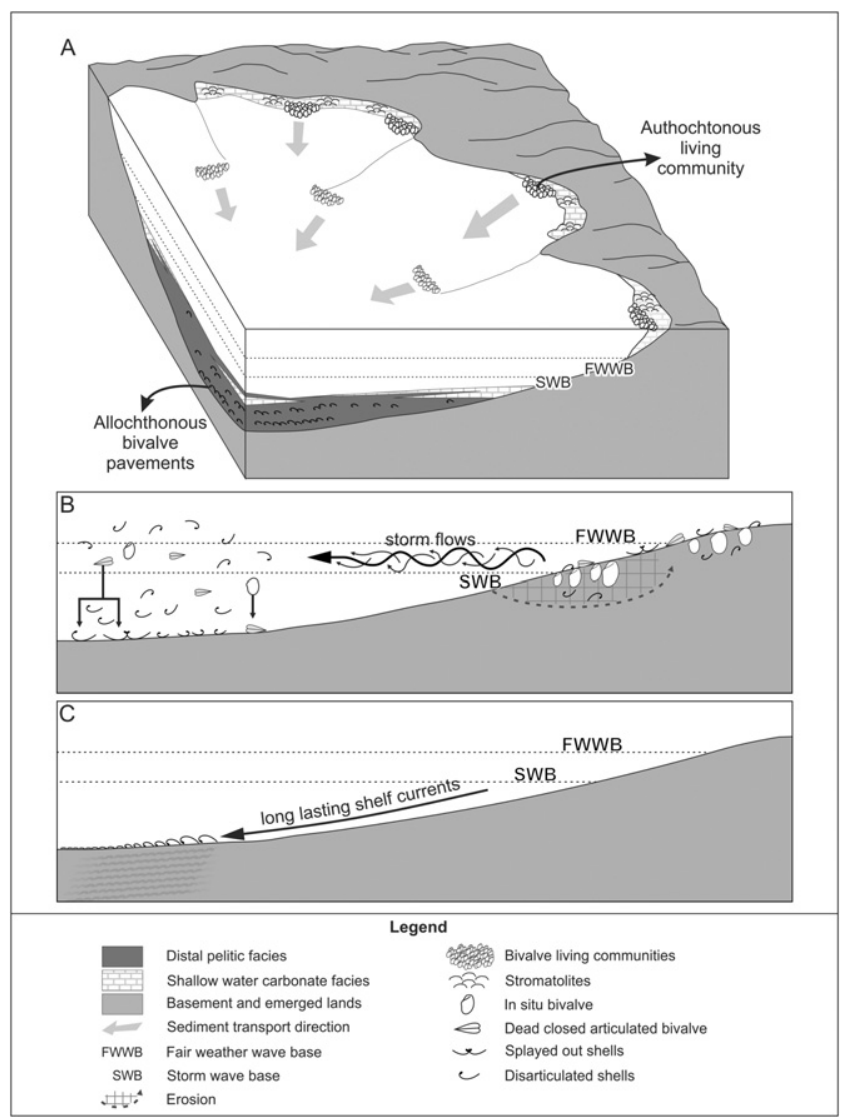

Fig. 12. A: Schematic diagram showing the deposition of the bivalve-rich pavements in distal facies of the Irati Formation. The shells were transported by storm flows from shallow water habitats, where thrived a bivalve fauna in "Irati Sea" (B). Posteriorly, the shells were sorted and oriented by long-lasting shelf currents.

Actually, our model above traces a close parallel with the northeastern China Mesozoic fossil record, as documented by Fürsich et al. (2016). According to these authors, bivalves from Jurassic and Early Cretaceous benthic lake faunas living in marginal habitats were transported to distal areas by storm events. Detailed taphonomic evidence shows that some bivalves were transported alive and died articulated on the anoxic mud bottoms due to the hostile conditions prevailing there (Fürsich et al., 2016). Hence, although the bivalve concentrations were composed of closed articulated bivalves, the shells are mainly allochthonous. The rare articulated shells in mudstones of the Irati Formation were probably transported from shallow water settings to distal areas in a similar manner described by Fürsich et al. (2016). Therefore, the Irati bivalves were preserved out of their living bottoms. However, while the outof-habitat movement of skeletal remains is rare (but see Flessa, 1998, for exceptional exceptions), small within-habitat transport of shells is extremely common in shallow-water environments (Kidwell and Bosence, 1991, p. 158). The unusual presence of shallow-water bivalves in offshore deposits of the Irati Formation shows that the out-of-habitat transport of shells may be relevant in those sedimentary successions generated in intracratonic basins, where geomorphic structures such as the continental slope were missing, and high-energy episodic events (i.e., storms, tsunamis) occurred especially during shallowing episodes.

\subsection{Depositional cycle patterns}

Figure five shows that at least three coarsening-upward regressive cycles can be recognized in the investigated interval of the Irati Formation. The meter-scale cycles are considered excellent proxies for identifying small-scale fluctuations in the water level (Kerans and Tinker, 1997) and are here interpreted as a product of high-frequency oscillations in the epeiric sea level. As discussed, the association of the facies succession suggests deposition in anoxic waters under reducing bottom conditions, as indicated by the presence of eodiagenetic arsenopyrite concretions and the high content of organic matter preserved in the black shales (Oliveira, 2012). The incidence of massive claystones indicates deposition of muds and silts by suspension fallout in distal environments, far away from the reworking of day-to-day (background) processes by fair-weather and storm-wave orbitals. Changes in storm intensity are responsible for the intrabasinal transport of whole bivalve shells and comminuted shell debris from shallow-water sites, which eventually led to the formation of shell pavements or bioclast-rich claystones. The fairly regular alternations of barren claystones and shell pavements illustrate the cyclic pattern of deposition. In this context, any increase in the rock granulation (mud shale to silty shale) and the presence of fossil-rich levels are interpreted as a product of changes in the water-level base and/or perturbations in the offshore environment. In other words, the fossil-rich layers at the top of cycle 1 and the grainstone bed in the uppermost portion of the succession were produced by proximal sediments and organisms transported from the shallower portions of the basin margins, probably by episodic currents or wave orbitals, during periods of falling sea levels (Fig. 5). Thus, the recurrence of coarsening upward cycles is strongly suggestive of highfrequency pulses of regressive sedimentation. At the outcrop scale, the progradational architecture of the succession is indicated by the upward decrease in the thickness of each cycle. This tendency culminates with the grainstone facies of the Assistência Member, suggesting the input of proximal carbonatic sediments in an increasingly shallower water body.

\subsection{Evolutionary implications: were Runnegar and Newell (1971) right?}

The find of bivalves in the Irati Formation has important implications for our understanding of the evolution of the endemic molluscan fauna of the Permian Passa Dois Group (Fig. 1). In their benchmark monograph on these bivalves, Runnegar and Newell (1971) were the first authors to confidently demonstrate that they belong to the families Pachydomidae (=Megadesmidae) and Astartidae. They noted the morphological similarity among various pachydomid bivalves of the Passa Dois Group fauna with those found in the Australian Permian successions. Simões et al. (1997) demonstrated that all endemic pachydomid bivalves of the Passa Dois Group belong to a monophyletic group (the Plesiocyprinellinae), which were derived from marine ancestors.

For many years, a major objection to the model of the endemic evolution of the Passa Dois Group bivalves was the complete absence of shells in the Irati Formation, which is intercalated between the Palermo and Serra Alta formations (Fig. 4). Simões (1992) recorded the presence of marine Gondwanean bivalves (i.e., Megadesmus, Pyramus, and Astartila) in the Palermo Formation. Thus, a marine stock of pachydomid bivalves populated the bottoms of the Paraná Basin prior the Irati anoxic event.

The abundant and diverse endemic pachydomid bivalves found in the Teresina Formation (see Fig. 1) lived in extremely shallow-water bottoms (see Simões and Kowalewski, 1998; Simões et al., 1998). Hence, it is reasonable to assume that their ancestors may also have inhabited similar marginal environments in the Paraná Basin (Runnegar and Newell, 1971, p. 15). Our data corroborate this assumption, since the recorded bivalves probably lived in marginal, oxic to dysoxic environments of the Irati Formation, where a poorly diversified shallow-water fauna thrived (Runnegar and Newell, 1971). Not surprisingly, the shells found in the Irati Formation were assigned as shallowwater bivalves. Even more importantly, the non-specialized genus Plesiocyprinella is present in the assemblage, just a few meters above the underlying Palermo Formation, which contains shells of the closely related genus Megadesmus (see also Runnegar and Newell, 1971). Finally, Plesiocyprinella is one of the oldest known representatives of endemic Pachydomidae in the Passa Dois Group. In other words, even without 
this information, Runnegar and Newell (1971) were right in several key points about the evolutionary history of the endemic molluscan fauna of the Passa Dois Group. The main one is the continuous development of the bivalve faunas throughout the underlying Rio Bonito and Palermo formations (Guatá Group) and the overlying Irati and Serra Alta formations (Passa Dois Group) (see also Simões, 1992).

\section{Summary and conclusions}

This paper sheds light on our knowledge about the genesis of shellrich concentrations in black shales (see also Fürsich et al., 2016). During the deposition of the studied mudrock succession, conditions of soupy substrates and extremely low oxygen content (dysoxic-anoxic) prevailed in the bottom waters. We convincingly demonstrated that contemporaneous with the deposition of the anoxic offshore muds, a bivalve mollusk fauna thrived in oxic-dysoxic bottoms of the Paraná Basin. Their preservation in distal deposits is, however, the product of shell transport by storm flows from shallow water habitats and subsequent sorting by long-lasting shelf currents in offshore settings. Thus, the bivalve-rich pavements are thin complex shell concentrations (sensu Kidwell, 1991), despite their simple internal stratigraphy.

The foregoing scenario has important paleoecologic, paleogeographic and evolutionary implications. First, it indicates that benthic invertebrates thrived in large numbers in the margins of the basin during the deposition of the shales of the Irati Formation. Second, the mono- to paucispecific nature of the studied bivalve-rich pavements is partly due to mechanical sorting. Hence, these offer us only a limited view of the bivalve fauna that lived in the contemporary marginal settings. Third, the presence of endemic infaunal pachydomid bivalves in the pavements indicates that the fauna developed in situ while the basin connection with the open ocean (Panthalassa) was restricted or absent. This idea was defended by previous authors (i.e., K. Beurlen, J.C. Mendes, N. Newell, B. Runnegar, M.G. Simões) without having a consistent record of bivalves in the Irati Formation. Therefore, the origin of the endemic Passa Dois molluscan fauna occurred somewhere between the interval of the deposition of the underlying Palermo Formation and the Irati Formation, and not in the overlying Serra Alta and Teresina formations as previously thought (see the discussions in Runnegar and Newell, 1971; Simões et al., 1998).

As shown above, the anoxic crisis represented by the deposition of the organic-rich shales of the Irati Formation was a limiting factor to bivalve colonization of the distal settings (below the storm-wave base) of the Paraná Basin, but not to the life at its margins, where dysoxic or even oxic conditions may have existed. Actually, the rare shell-rich pavements in distal deposits of the Irati succession do not reflect the normal (day-by-day) depositional conditions on the offshore basin floor. They are primarily event beds, and thus sedimentologic indicators of brief episodic ventilation of the dysoxic-anoxic bottoms.

Finally, during the deposition of the overlying Serra Alta Formation, as a result of the improved bottom water circulation into the Paraná Basin, the pachydomid bivalves diversified dramatically, especially in dysoxic bottoms (see Bondioli, 2014; Bondioli et al., 2015; Warren et al., 2015; Matos, 2016). This represents the first true event of endemic bivalve expansion into basin bottoms following the Irati anoxic event. Our results considerably change the known vertical range of these unique bivalves (see Fig. 1), whose first appearance occurred at least $\sim 10$ million years earlier than previously thought.

\section{Acknowledgements}

Financial supports were provided by FAPESP (Grant 2012/12508-6) and CNPq (Grants 302903/2012-7 and 444070/2014-1). Our thanks are also extended to the Department of Zoology, IBB/UNESP, Department of Sedimentary and Environmental Geology, IGc/USP and Department of Applied Geology, IGCE/UNESP, which provided laboratory and logistic facilities. The review by Lidia Tackett and the comments made by the editor are also gratefully acknowledged. We also thank Andrea Tintori for assistance with some old references.

\section{References}

Allison, P.A., Briggs, D.E.G., 1991. Taphonomy: Releasing the Data Locked in the Fossil Record. Plenum, New York

Allmon, R.A., 1985. "Butterflied" bivalves as paleoenvironmental indicators. $98^{\circ}$ Annual meeting of the Geological Society of America, Orlando. Geological Society of America Abstracts Programs. 17, p. 512

Almeida, F.F.M., Barbosa, O., 1953. Geologia das Quadrículas de Piracicaba e Rio Claro. 143. Boletim da Divisão de Geologia e Mineralogia, Estado de São Paulo.

Alves, L.S.R., 1994. Integração Entre a Lignoflora e a Palinologia no Afloramento Passo São Borja (Fm. Irati - Bacia do Paraná). Unpublished Masters Thesis. Universidade Federal do Rio Grande do Sul (174pp).

Amaral, S.E., 1971. Geologia e petrologia da Formação Irati (Permiano) no Estado de São Paulo. 2. Boletim do IGA:pp. 3-81. http://dx.doi.org/10.11606/issn.2316-9001. v2i0p03-81.

Araújo, D.C., 1976. Taxonomia e relação dos Proganosauria da Bacia do Paraná. An. Acad. Bras. Cienc. 48 (1), 91-116.

Araújo, L.M., 2001. Análise da Expressão Estratigráfica dos Parâmetros de Geoquímica Orgânica nas Seqüências Deposicionais Irati. Unpublished PhD Thesis. Universidade Federal do Rio Grande do Sul (307pp).

Araújo, L.M., Rodrigues, R., Scherer, C.M.S., 2001. Sequências deposicionais Irati: arcabouço químio-estratigráfico e inferências paleoambientais. Ciência-TécnicaPetróleo 20, 193-202.

Beder, R., 1923. Sobre un hallazgo de fossils pérmicos en Villarrica (Republica del Paraguay). Boletin de la Academia Nacional de Ciências en Córdoba. 27, pp. 9-12.

Beurlen, K., 1954. Horizontes fossilíferos das camadas Serra Alta do Paraná. Boletim da Divisão de Geologia e Mineralogia. 152.

Beurlen, K., 1957a. Faunas salobras fósseis e o tipo ecológico-paleogeográfico das faunas gondwânicas no Brasil. An. Acad. Bras. Cienc. 29, 229-241.

Beurlen, K., 1957b. Um Lamelibrânquio do Folhelho Irati de São Mateus do Sul. 98. Notas Preliminares e Estudos. Divisão de Geologia e Mineralogia, Estado do Paraná, pp. 1-5.

Bondioli, J.G, 2014. Dinâmica Sedimentar, Tafonomia e Paleoambientes da Facies de Offshore da Formacão Serra Alta, Permiano, Bacia do Paraná: um Estudo de Caso no Estado de São Paulo, Brasil. Unpublished Masters Thesis. Universidade de São Paulo (130pp).

Bondioli, J.G., Matos, S.A., Warren, L.V., Assine, M.L., Riccomini, C., Simões, M.G., 2015. The interplay between event and background sedimentation and the origin of fossil-rich carbonate concretions: a case study in Permian rocks of the Paraná Basin, Brazil. Lethaia 48:522-539. http://dx.doi.org/10.1111/let.12124.

Brett, C.E., Baird, G.C., 1986. Comparative taphonomy: a key to paloenvironmental interpretation based on fossil preservation. PALAIOS 1:207-227. http://dx.doi.org/10. 2307/3514686

Brett, C.E., Zambito IV, J.J., Schindler, E., Becker, T., 2012a. Diagenetically-enhanced trilobite obrution deposits in concretionary limestones: the paradox of 'rhythmic events beds'. Palaeogeogr. Palaeoclimatol. Palaeoecol. 367-368:30-43. http://dx.doi.org/10. 1016/j.palaeo.2011.12.004

Brett, C.E., Zambito IV, J.J., Hundra, B.R., Schindler, E., 2012b. Mid-Paleozoic trilobite Lagerstatten: models of diagenetically enhanced obrution deposits. PALAIOS 27: 326-345. http://dx.doi.org/10.2110/palo.2011.p11-040r.

Cadée, G.C., 2002. Floating articulated bivalves, Texel, North Sea. Palaeogeogr. Palaeoclimatol. Palaeoecol. 183:355-359. http://dx.doi.org/10.1016/S0031-0182(01)00487-4.

Caires, E.T., 2005. Tratamento especial dos dados paleontológicos do subgrupo Irati no Estado de São Paulo - Brasil. Graduation Monograph. Universidade de Campinas (59pp).

Calça, C.P., Fairchild, T.R., 2012. Petrographic approach to the study of organic microfossils from the Irati subgroup (Permian, Paraná Basin, Brazil). J. S. Am. Earth Sci. 35:51-61. http://dx.doi.org/10.1016/j.jsames.2011.10.005.

Chahud, A., Petri, S., 2015. Geology and taphonomy from the base of the Taquaral Member, Irati Formation (Permian, Paraná Basin), Brazil. Acta Geol. Pol. 65, 379-387.

Chattopadhyay, D., Rathie, A., Das, A., 2013. The effect of morphology on postmortem transportation of bivalves and its taphonomic implications. PALAIOS 28:203-209. http://dx.doi.org/10.2110/palo.2012.p12-103r.

Cooper, M.R., Kensley, B., 1984. Endemic South America Permian bivalve mollusks from the Ecca of South Africa. J. Paleontol. 58, 1360-1363.

Costa, R.H.C., 1981. Madeiras gimnospérmicas da Formação Irati no Rio Grande do Sul, contribuição ao estudo anatômico e paleoecológico. Unpublished Master Thesis. Universidade Federal do Rio Grande do Sul (99 p).

David, J.M., 2014. Sistemática, Paleoecologia e Bioestratigrafia dos Bivalves Permianos das Formações Rio Do Rasto (Bacia do Paraná, Brasil) e Waterford (Bacia do Karoo, África do Sul). Unpublished PhD Thesis. Universidade de São Paulo (165pp).

David, J.M., Simões, M.G., Anelli, L.E., Rosemarie, R., Holzfoerster, F., 2011. Permian bivalve molluscs from the Gai-As Formation, northern Namibia: systematics, taphonomy and biostratigraphy. Alcheringa 35 (4):497-516. http://dx.doi.org/10.1080/03115518. 2011.538908.

Delaney, P.J.V., Goni, J., 1963. Correlação preliminar entre as formações gondwanicas do Uruguai e Rio Grande do Sul, Brasil. Boletim Paranaense de Geografia. 8-9, pp. 3-21.

Etter, W., 1996. Pseudoplanktonic and benthic invertebrates in the Middle Jurassic Opalinum Clay, northern Switzerland. Palaeogeogr. Palaeoclimatol. Palaeoecol. 126: 325-341. http://dx.doi.org/10.1016/S0031-0182(96)00036-3.

Euzébio, R.S., Reis, D.E.S., Brito, M.A.R.C., Bergamaschi, S., Martins, M.V.A., Rodrigues, R., 2016. Oil generation potential assessment and paleoenvironmental interpretation 
of Irati Formation (Lower Permian) in northwestern of Paraná Basin (Brazil). J. Sediment. Environ. 1:261-274. http://dx.doi.org/10.12957/jse.2016.23388.

Faure, K., Cole, D., 1999. Geochemical evidence for lacustrine microbial blooms in the vast Permian Main Karoo, Parana, Falkland Islands and Huab basins of southwestern Gondwana. Palaeogeogr. Palaeoclimatol. Palaeoecol. 152 (3-4):189-213. http://dx. doi.org/10.1016/S0031-0182(99)00062-0.

Flessa, K.W., 1998. Well-traveled cockles: Shell transport during the Holocene transgression of the southern North Sea. Geology 26:187-190. http://dx.doi.org/10.1130/ 0091-7613(1998)026<0187:WTCSTD>2.3.CO;2.

Fürsich, F.T., Oschmann, W., 1993. Shell beds as tool in basin analysis: the Jurassic of Kachchh, western India. J. Geol. Soc. Lond. 150:169-185. http://dx.doi.org/10.1144/ gsjgs.150.1.0169.

Fürsich, F.T., Werner, W., Delvene, G., García-Ramos, J.C., Bermúdez-Rochas, D.D., Piñuela, L., 2012. Taphonomy and palaeoecology of high-stress benthic associations from Upper Jurassic of Asturias, northern Spain. Palaeogeogr. Palaeoclimatol. Palaeoecol. 358-360:1-18. http://dx.doi.org/10.1016/j.palaeo.2012.07.006.

Fürsich, F.T., Pan, Y.H., Wang, Y.Q., 2016. Biostratinomy of bivalves from Jurassic and Early Cretaceous lakes of NE China. Palaeoworld 25:399-405. http://dx.doi.org/10.1016/j. palwor.2015.11.001.

Goldberg, K., Humayun, M., 2016. Geochemical paleoredox indicators in organic-rich shales of the Irati Formation, Permian of the Paraná Basin, southern Brazil. Braz. J. Geol. 46:377-393. http://dx.doi.org/10.1590/2317-4889201620160001.

Hachiro, J., 1991. Litotipos, associações faciológicas e sistemas deposicionais da Formação Irati no Estado de São Paulo. Unpublished Master Thesis. Universidade de São Paulo (175pp).

Hachiro, J., 1996. O Subgrupo Irati (Neopermiano) da Bacia do Paraná. Unpublished PhD thesis. Universidade de São Paulo (196pp).

Hachiro, J., Coimbra, A.M., Matos, S.L.F., 1993. 0 caráter cronoestratigráfico da Unidade Irati. Simpósio sobre cronoestratigrafia da Bacia do Paraná, Rio Claro. Livro de Resumos, pp. 62-63.

Harrington, H.J., 1956. Handbook of South America geology. The Geological Society of America Memoirs. 65, pp. 101-128.

Holz, M., França, A.B., Souza, P.A., Iannuzzi, R., Rohn, R., 2010a. A stratigraphic chart of the Late Carboniferous/Permian succession of the eastern border of the Parana Basin, Brazil, South America. J. S. Am. Earth Sci. 29:381-399. http://dx.doi.org/10. 1016/j.jsames.2009.04.004

Holz, M., Kalkreuth, W., Rolim, S.B.A., 2010b. Extension of the Paraná Basin to offshore Brazil: implications for coal bed methane evaluation. Mar. Pet. Geol. 27:1119-1132. http://dx.doi.org/10.1016/j.marpetgeo.2010.01.013.

Holzfoerster, F., 2000. Sedimentology, Stratigraphy and Synsedimentary Tectonics of the Karoo Supergroup in the Huab and Waterberg-Erongo areas, N-Namibia. PhD thesis. University of Würzburg (298pp).

Holzfoerster, F., 2002. Sedimentology, stratigraphy and synsedimentary tectonics of the Karoo Supergroup in the Huab and Waterberg-Erongo areas, N-Namibia. Beringeria $30,1-144$.

Hunt, H.L., Maltais, M.J., Fugate, D.C., Chant, R.J., 2007. Spatial and temporal variability in juvenile bivalve dispersal: effects of sediment transport and flow regime. Mar. Ecol. Prog. Ser. 352, 145-159.

Kazubek, M.F., Simões, M.G., 2002. The lost fauna unearthed: Permian bivalves of the Irati Formation (Passa Dois Group), Paraná Basin, Brazil. Paleo - 2002, Porto Alegre. Paleontologia em Destaque. 40, p. 31.

Kazubek, M.F., Simões, M.G., 2003a. Permian bivalves of the Irati Formation (Passa Dois Group, Paraná Basin) and their paleoecological significance. XVIII Congresso Brasileiro de Paleontologia, Brasília. Boletim de Resumos, p. 161.

Kazubek, M.F., Simões, M.G., 2003b. Feições sedimentológicas, bioestratinômicas e estratigráficas das concentrações de bivalves do Membro Taquaral (Formação Irati, Grupo Passa Dois, Bacia do Paraná) e seus significados. Paleo-2003, Curitiba. Paleontologia em Destaque. 44, p. 29.

Kerans, C., Tinker, S.W., 1997. Sequence stratigraphy and characterization of carbonate reservoirs. SEPM Spec. Publ. Short Course Notes 40 (165 pp).

Kidwell, S.M., 1991. The stratigraphy of shell concentrations. In: Allison, P.A., Briggs, D.E.G. (Eds.), Taphonomy, Releasing the Data Locked in the Fossil Record. Topics in Geobiology Vol. 9. Plenum Press, New York, pp. 211-290.

Kidwell, S.M., Bosence, D.W.J., 1991. Taphonomy and time-averaging of marine shelly faunas. In: Allison, P.A., Briggs, D.E.G. (Eds.), Taphonomy, Releasing the Data Locked in the Fossil Record. Topics in Geobiology Vol. 9. Plenum Press, New York, pp. 115-209.

Kidwell, S.M., Holland, S.M., 1991. Field description of coarse bioclastics fabrics. PALAIOS 6:426-434. http://dx.doi.org/10.2307/3514967.

Kidwell, S.M., Fürsich, F.T., Aigner, T., 1986. Conceptual framework for the analysis and classification of shell concentration. PALAIOS 1:228-238. http://dx.doi.org/10.2307 3514687.

Lages, L.C., 2004. A Formação Irati (Grupo Passa Dois, Permiano, Bacia do Paraná) no furo de Sondagem FP-01-PR (Sapopema, PR). Master Thesis. Universidade Estadual Paulista "Júlio de Mesquita Filho" (117 pp).

Lavina, E.L., 1991. Geologia Sedimentar e Paleogeografia do Neopermiano e Eotriássico (Intervalo Kazaniano-Scythiano) da Bacia do Paraná. PhD thesis. Universidade Federal do Rio Grande do Sul (333 pp).

Lavina, E.L., Araujo-Barberena, D.C., Azevedo, S.A.K., 1991. Tempestades de inverno e altas taxas de mortalidade de répteis mesossauros: um exemplo a partir do afloramento Passo São Borja, RS. Pesquisas 18, 64-70.

Limarino, C.O., Césari, S.N., Spalletti, L.A., Taboada, A.C., Isbell, J.L., Geuna, S., Gulbranson, E.L., 2014. A paleoclimatic review of southern South America during the late Paleozoic: a record from icehouse to extreme greenhouse conditions. Gondwana Res. 25: 1396-1421. http://dx.doi.org/doi:10.1016/j.gr.2012.12.022.

López Gamundi, O.R., Conaghan, P., Rossello, E.A., Cobbold, P.R., 1995. The Tunas Formation (Permian) in the Sierras Australes Foldbelt, East-Central Argentina: evidence of syntectonic sedimentation in a Varisican foreland basin. J. S. Am. Earth Sci. 8 (2), $129-142$.

Martinez, G.H.P., 2004. Faunas del Pérmico y Permo-Triásico de Uruguay. Bioestratigrafia, Paleobiogeografia y Sistemática. Unpublished PhD Thesis. Facultad de Ciencias, Uruguay (234pp).

Matos, S.A., 2016. Tafonomia e Paleoecologia de Bivalves Permianos em Fácies Siliciclásticas Deficientes em Oxigênio: o Exemplo das Formações Irati e Serra Alta, Bacia do Paraná, Brasil. Ph.D. Thesis. IGc-Universidade de São Paulo (183pp).

Matos, S.A., Pretto, F.A., Simões, M.G., 2013. Tafonomia dos Pygocephalomorpha (Crustacea, Peracarida, Malacostraca), Permiano, Bacia do Paraná, Brasil, e seu significado paleoambiental. Rev. Bras. Paleontol. 16:97-114. http://dx.doi.org/10. 4072/rbp.2013.1.08

Maynard, J.B., Chocyk, J.M., Gaines, R.R., Krekeler, M.P., Prokopenko, M., Summers, A.M., Huff, W.D., 1996. Bentonites in the Late Permian (Tatarian) Irati Formation of Brazil: geochemistry and potential of stratigraphic correlation. XXVIII Geological Society of America Annual Meeting, Denver, p. 280 Abstracts.

Mendes, J.C., 1952. A Formação Corumbataí na região do Rio Corumbataí. (Estratigrafia e descrição dos lamelibrânquios). Boletim da Faculdade de Filosofia, Ciências e Letras da Universidade de São Paulo 145 (Geologia 8), pp. 1-119.

Mendes, J.C., 1967. The Passa Dois Group (the Brazilian portion of the Paraná Basin). In: Bigarella, J.J., Becker, R.D., Pinto, I.D. (Eds.), First International Symposium on the Gondwana Stratigraphy and Palaeontology, Curitiba. Problems in Brazilian Gondwana Geology, pp. 119-166.

Milani, E.J., França, A.B., Schneider, R.L., 1994. Bacia do Paraná. Boletim de Geociências da Petrobrás. 8, pp. 69-82.

Milani, E.J., Melo, J.H.G., Souza, P.A., Fernandes, L.A., França, A.B., 2007. Bacia do Paraná Boletim de Geociências da Petrobras. 15, pp. 265-287.

MINEROPAR - Serviço Geológico do Paraná, 2006. Mapa Geológico do Estado do Paraná, scale: $1: 650.000$

Mones, A., Figueiras, A., 1981. A geo-paleontological synthesis of the Gondwana formations of Uruguay. In: Creswell, V.M.M., Vella, P. (Eds.), V International Gondwana Symposium. Balkema, p. 47 Proceedings.

Monteiro, S.M., 1979. Contribuição ao estudo paleoxilológico da Formação Irati do Rio Grande do Sul. Unpublished Master Thesis. Universidade Federal do Rio Grande do Sul (143pp).

Mozley, P.S., 1996. The internal structure of carbonate concretions in mudrocks: a critical evaluation of the conventional concentric model of concretion growth. Sediment. Geol. 103:85-91. http://dx.doi.org/10.1016/0037-0738(95)00087-9.

Mussa, D., Gama de Carvalho, R., Santos, P.R., 1980. Estudo Estratigráfico e Paleoecológico em Ocorrências Fossilíferas da Formação Irati, Estado de São Paulo, Brasil. 11. Boletim IG-USP, pp. 142-149.

Neves, J.P., Rohn, R., Simões, M.G., 2010. Tafonomia de biválvios em calcários oolíticos da Formação Teresina (Bacia do Paraná, Permiano Médio, Prudentópolis, PR). Geologia USP Série Científica 10 (3), 19-36.

Neves, J.P., Rohn, R., Simões, M.G., 2011. Tafonomia de tempestitos conchíferos amalgamados da Formação Teresina em Rio Preto (Estado do Paraná, Permiano Médio, Bacia do Paraná) e suas implicações paleoambientais. Geologia USP. Série Científica 11, 131-147.

Oelofsen, B., Araújo, D.C., 1983. Palaeoecological implications of the distribution of mesosaurid reptiles in the Permian Irati sea (Paraná Basin), South America. Rev. Bras. Geosci. 13 (8), 1-6.

Oelofsen, B., Araújo, D.C., 1987. Mesosaurus tenuidens and Stereosternum tumidum from the Permian Gondwana of both southern Africa and South America. S. Afr. J. Sci. 83, 370-372

Oliveira, A.F., 2012. Paleotemperaturas e Paleofluidos da Formação Irati na Borda leste da Bacia do Paraná: Implicações para a Geração e Migração de Hidrocarbonetos. Unpublished Master Thesis. Universidade de São Paulo (115 pp).

Oschmann, W. 1991. Distribution, dynamics and palaeoecology of Kimmeridgian (Upper Jurassic) shelf anoxia in western Europe. In: Tyson, R.V., Pearson, T.H. (Eds.), Modern and Ancient Continental Shelf Anoxia 58. Geological Society, London, pp. 381-395 Special Publication.

Padula, V.T., 1968. Estudos geológicos da Formação Irati, sul do Brasil. Boletim Técnico da Petrobrás 11 (3), 407-430.

Piñeiro, G., Morosi, E., Ramos, A., 2012a. Pygocephalomorph crustaceans from the Early Permian of the Uruguay: constraints on taxonomy. Rev. Bras. Paleontol. 15:33-48. http://dx.doi.org/10.4072/rbp.2012.1.03.

Piñeiro, G., Ramos, A., Scarabino, F., Goso, C., Laurin, M., 2012b. Unusual environmental conditions preserve a Permian mesosaur bearing Konservat-Lagertätten from Uruguay. Acta Palaeontol. Pol. 57:299-318. http://dx.doi.org/10.4202/app.2010.0113.

Plotnick, R., 1986. Taphonomy of a modern shrimp: implications for the arthropod fossil record. PALAIOS 1, 286-293.

Posenato, R., Bassi, D., Avanzini, M., 2013. Bivalve pavements from shallow-water blackshales in the Early Jurassic of northern Italy: a record of salinity- and oxygen-depleted environmental evolutionary dynamics. Palaeogeogr. Palaeoclimatol. Palaeoecol. 369: 262-271. http://dx.doi.org/10.1016/.jpalaeo.2012.10.032.

Ricardi-Branco, F., Caires, E., Silva, A.M., 2008. Levantamento de ocorrências fósseis nas pedreiras de calcário do Subgrupo Irati no Estado de São Paulo, Brasil. Rev. Bras. Geosci. 38, 80-88.

Rohn R. 1994. Evolução Ambiental da Bacia do Paraná Durante o Neopermiano no Leste de Santa Catarina e do Paraná. Unpublished PhD Thesis. Universidade de São Paulo, São Paulo (480pp).

Rohn, R., 2007. The Passa Dois Group (Paraná Basin, Permian): investigations in progress. Extended Abstracts - I Workshop Problems in the Western Gondwana Geology, South America - Africa correlations: du Toit Revisited, pp. 151-157.

Rohn, R., Lages, L.C., Penatti, J.R.R., 2003. Litofácies da Formação Irati no furo de sondagem FP-01-PR (Permiano, borda leste da Bacia do Paraná). II Congresso Brasileiro de P\&D em Petróleo \& Gás, Rio de Janeiro. 1, pp. 1-6 Resumos. 
Rösler, O., 1974. Aspectos tegumentários de mesossaurídeos (Reptilia) do Permiano Formação Irati - Estado de São Paulo. Ciência e Cultura 26 (7), 190-191.

Rösler, O., Tatizana, G., 1985. As membranas natatórias em Stereosternum tumidum. DNPM - Coletânea de Trabalhos Paleontológicos. 27, pp. 129-131.

Rösler, O., Rohn, R., Albamonte, L., 1981. Libélula permiana do Estado de São Paulo, Brasil (Formação Irati): Gondvanoptilon brasiliense gen. et sp. nov. II Congresso LatinoAmericano de Paleontologia, Porto Alegre. 2, pp. 221-232 Anais.

Runnegar, B., Newell, N.D., 1971. Caspian-like relicts molluscan fauna in the South American Permian. Bull. Am. Mus. Nat. Hist. 146, 1-66.

Santos, R.V., Souza, P.A., Oliveira, C.G., Dantas, E.L., Pimentel, M.M., Araújo, L.M., Alvarenga, C.J.S., 2006. SHRIMP U-Pb zircon dating and palynology of bentonitic layers from the Permian Irati Formation, Paraná Basin, Brazil. Gondwana Res. 9:456-463. http://dx doi.org/10.1016/j.gr.2005.12.001.

Schatz, W., 2005. Palaeoecology of the Triassic black shale bivalve Daonella-new insights into an old controversy. Palaeogeogr. Palaeoclimatol. Palaeoecol. 216:189-201. http://dx.doi.org/10.1016/j.palaeo.2004.11.002.

Schneider, R.L., Mühlmann, H., Tommasi, E., Medeiros, R.A., Daemon, R.F., Nogueira, A.A 1974. Revisão estratigráfica da Bacia do Paraná. In: Sanguinetti, Y.T. (Ed.), XXVIII Congresso Brasileiro de Geologia, Porto Alegre. Anais. Vol. 1, pp. 41-65.

Selover, R.W., Gastaldo, R.A., Nelson, R.E., 2005. An estuarine assemblage from the Middle Devonian Trout Valley Formation of Northern Maine. PALAIOS 20:192-197. http://dx. doi.org/10.2110/palo.2004.p04-16.

Simões, M.G., 1992. Pelecípodes da Formação Palermo (Permiano) de São Sepé (RS) e Guiratinga (MT): implicações na evolução da fauna Neopaleozóica da Bacia do Paraná, Brasil. PhD Thesis. Universidade de São Paulo, São Paulo (286p).

Simões, M.G., Anelli, L.E., 1995. Runnegariella, um novo gênero de Megadesmidae (Pelecypoda) da Formação Corumbataí (Neopermiano), Bacia do Paraná, Brasil. Geociências 14 (2), 161-173.

Simões, M.G., Kowalewski, M., 1998. Complex shell beds as paleoecological puzzles: a case study from the upper Permian of the Paraná Basin, Brazil. Facies 38, 175-196.

Simões, M.G., Torello, F.F., Rocha-Campos, A.C., 1996. Gênese e classificação da coquina de Camaquã (Assembleia de Pinzonella neotropica), Formação Corumbataí (Permiano Superior), Rio Claro, SP. An. Acad. Bras. Cienc. 68 (4), 545-557.

Simões, M.G., Marques, A.C., Mello, L.H.C., Anelli, L.E., 1997. Philogenetic analysis of the genera of the extinct family Megadesmidae (Pelecypoda, Anomalodesmata), with remarks on its paleoecology and taxonomy. J. Comp. Biol. 2, 75-90.

Simões, M.G., Rocha-Campos, A.C., Anelli, L.E., 1998. Paleoecology and evolution of Permian pelecypod assemblages (Paraná Basin) from Brazil. In: Johnston, P.A., Haggart, J.W. (Eds.), Bivalves - An Eon of Evolution: Paleobiological Studies Honoring Norman D. Newell. University of Calgary Press, Calgary, pp. 443-452

Simões, M.G., Matos, S.A., Anelli, L.E., Rohn, R., Warren, L.V., David, J.M., 2015. A new Permian bivalve-dominated assemblage in the Rio do Rasto Formation, Paraná Basin, Brazil: faunal turnover driven by regional-scale environmental changes in a vast epeiric sea. J. S. Am. Earth Sci. 64:14-26. http://dx.doi.org/10.1016/j.jsames. 2015.09.009.
Soares, M.B., 2003. A taphonomic model for the Mesosauridae assemblage of the Irati Formation (Paraná Basin, Brazil). Geol. Acta 1 (4), 349-361.

Sörliin, T., 1988. Floating behaviour in the tellinid bivalve Macoma balthica (L.). Oecologia 77, 273-277.

Sousa, S.H.M., Suguio, K., Castro, J.C., 1991. Sedimentary facies of the Estrada Nova and Corumbataí Formations (Late Paleozoic of the Paraná Basin) in the State of São Paulo, Brazil. In: Ulbrich, H., Rocha Campo, A.C. (Eds.), VII International Gondwana Symposium, São Paulo. Proceedings, pp. 161-172.

Stollhofen, H., Stranistreet, I.G., Rohn, R., Holzfoerster, F., Wanke, A., 2000. The Gai-As lake system, northern Namibia and Brazil. In: Glerlowski-Kordesch, E.H., Kelts, K.R. (Eds.), Lake Basins Through Space and Time. Tulsa, AAPG Studies in Geology Vol. 46, pp. 87-108.

Subacius, S.M., Amaral, S.E., 1983. Estudo biogeoquímico da matéria orgânica preservada em folhelhos pirobetuminosos próximos a soleiras de diabásio: Formacão Irati. An. Acad. Bras. Cienc. 55 (1), 45-53.

Tintori, A., 1995. Biomechanical fragmentation in shell-beds from the late Triassic of the Lombardian Basin (Northern Italy). Preliminary report. Riv. Ital. Paleontol. Stratigr. 101, 371-380.

Wanke, A., 2000. Karoo-Etendeka Unconformites in NW Namibia and Their Tectonic Implications. Unpublished PhD Thesis. Würzburg University (116 pp).

Warren, L.V., Almeida, R.P., Hachiro, J., Machado, R., Roldan, L.F., Steiner, S.S., Chamani, M.A.C., 2008. Evolução sedimentar da Formação Rio do Rasto (Permo-Triássico da Bacia do Paraná) na porção centro sul do estado de Santa Catarina, Brasil. Rev. Bras. Geosci. 38, 213-227.

Warren, L.V., Assine, M.L., Simões, M.G., Riccomini, C., Anelli, L.E., 2015. A Formação Serra Alta, Permiano, no Centro-Leste do Estado de São Paulo, Bacia do Paraná, Brasil. Braz. J. Geol. 45:127-142. http://dx.doi.org/10.1590/23174889201500010008.

Watkins, R., 1974. Palaeobiology of an offshore molluscan fauna from the California Oligocene. Palaeogeogr. Palaeoclimatol. Palaeoecol. 15:245-266. http://dx.doi.org/10. 1016/0031-0182(74)90002-9.

Wesselingh, F.P., 2007. Long-lived lake molluscs as island faunas: a bivalve perspective. In: Renema, W. (Ed.), Biogeography, Time and Place: Distributions, Barriers and IslandsTopics in Geobiology Series Vol. 29. Springer, Dordrecht :pp. 275-314. http://dx.doi.org/10.1007/978-1-4020-6374-9_9.

Wignall, P.B., Hallam, A., 1991. Biofacies, stratigraphic distribution and depositional models of British onshore Jurassic black shales. In: Tyson, R.V., Pearson, T.H. (Eds.), Modern and Ancient Continental Shelf Anoxia Vol. 58. Geological Society of London Special Publication, London, pp. 291-309.

Zalán, P.V., Wolff, S., Vieira, I.S., Astolf, M.A., Conceição, J.C.J., Zanotto, O., Appi, V.T., 1991. Tectonics and sedimentation of the Paraná Basin. VII International Gondwana Symposium, São Paulo. Proceedings, pp. 83-117. 